\title{
VISUAL IMAGERY AND CONSTRUCTION OF TERRITORIAL IDENTITY THROUGH ICONIC BUILDINGS. CASE STUDY: THE ROMANIAN ATHENAEUM, BUCHAREST
}

\author{
Florentina-Cristina MERCIU \\ University of Bucharest, Bucharest, Faculty of Geography, Interdisciplinary Center of Advanced Research on \\ Territorial Dynamics, ROMANIA \\ cristina.merciu@geo.unibuc.ro
}

\section{Oana-Ramona ILOVAN}

Babeş-Bolyai University, Cluj-Napoca, Faculty of Geography, Territorial Identities and Development Research Centre, ROMANIA; Humboldt-Universität zu Berlin, Geography Department, Unter den Linden 6, 10099, Berlin, GERMANY

oana.ilovan@ubbcluj.ro, oana-ramona.ilovan@hu-berlin.de

\section{Andreea-Loreta CERCLEUX}

University of Bucharest, Bucharest, Faculty of Geography, Interdisciplinary Center of Advanced Research on Territorial Dynamics, ROMANIA

loreta.cercleux@geo.unibuc.ro

DOI: http://doi.org/10.23740/TID120203

\section{ABSTRACT}

The built heritage, through the multiple meanings it associates (oldness, architectural, aesthetic, symbolic, authenticity), is characterized by uniqueness and irreversibility, being frequently related to the cultural and implicitly tourist image of cities. Due to the seniority of architectural heritage and the special relations established with the place and people, under the direct influence of the socio-cultural and political factors, it ensures the accumulation of symbols that codify the urban space. As a result, heritage buildings are associated with elements of territorial identity. Visual imagery is used as an argument to support the process of selecting significant buildings for local / national culture. These are promoted among the general public. Most of the time, the selection process aims at identifying representative buildings, a process that registers the influence of socio-cultural and politic factors. This article focuses on the socio-cultural evolution of the Romanian Athenaeum, a symbolic building of the Romanian culture. Based on a rich background of historical illustrations and recent observations, the authors analysed the symbols associated with the Romanian Athenaeum, in various historical periods. The authors used a sample of picture postcards with representations of the Athenaeum and interpreted the information they provided. The key results show the cultural role of the Athenaeum for the capital city, Bucharest, and its relation with the political factor, as this building was selected as the host for important political events with a deep historical charge, most often having the support of national authorities. In the course of time, the Athenaeum was represented constantly in picture postcards, as cultural building symbol and tourist attraction, due to its unique characteristics which emphasize its role as element of urban identity for Bucharest. At the same time, the interpretation of visual imagery allowed the decoding of the symbols and identification of the identity narrative and politics built around the Athenaeum, which, through the interactions generated by the socio-cultural and political plans, confer it the quality of symbolic building for the national and European culture.

Keywords: built heritage, iconic architecture, representations, picture postcards, cultural and national identity

Cite this articleas: Merciu, F.-C., Ilovan, O.-R. \& Cercleux, A.-L. (2020). Visual Imagery and Construction of Teritorial Identity through I conic Buildings. Case Study: The Romanian Athenaeum, Bucharest. Territorial Identity and Development, 5(1), 37-67. DOI: http://doi.org/10.23740/TID120203 


\section{INTRODUCTION}

The architectural and art heritage represents the elements through which cities identify in various ways: as cultural expressions, as support for development (Youssef, 2018), but also as functional links between people and the environment, buildings being part of the physical environment (Elhagla, Nassar \& Ragheb 2020). In the course of time, architecture has been a transcendental way to preserve identity and add new meaning, correlated with spatial planning (Youssef, 2018). Each city is unique from the perspective of its cultural heritage that imprints particular features in terms of urban fabric (urban morphology), as well as a specific atmosphere imprinted by the elements of intangible heritage, collages of history, prominent personalities of the city and the interactions that take place in the respective urban space (UNDESA, 2012).

The historical value of the monuments is conferred by the long period they endured and enriched their meaning through their usefulness (Feilden, 2013, quoted by Maroși, 2017). The etymology of the word monument, whose origin is from Latin - monumentum which means "memory," "remembrance," from the verb moneo-ere, to remember-, expresses the cognitive value of monuments and their ability to preserve people's memory (Curinschi-Vorona, 1996, quoted by Maroşi, 2017, p. 31).

Old buildings are among the most appreciated and admired historical monuments and, as a result, they are among the most frequently represented and promoted elements of cultural heritage (Watson \& Waterson, 2010). Old buildings generate an emotional response from the viewer (Watson \& Waterson, 2010; Kepczynska-Walczak \& Walczak, 2015). They are a symbol of the past, but which also has a present (they are used as tourist attractions due to the values that certify their advantaged position as works of art, monuments, relics, etc. (Watson \& Waterson, 2010). The materiality of cultural objectives consists of their authenticity value, the preservation of original forms, the privilege of being selected from the mass of architectural monuments (Watson \& Waterson, 2010), the aesthetic value associated with works of painting, sculpture (Kharitonov, Smirnova \& Vilenskii, 2019), which gives heritage buildings uniqueness and irreversibility (Sache, 2009, quoted by lorgulescu et al., 2011; KepczynskaWalczak \& Walczak, 2015), social, symbolic, scientific, commemorative values (Bedate, Herrero \& Sanz, 2004; Mason, 2002; Matečić, 2016; Merciu et al., 2020; Munasinghe, 2000; Navrud, 2005; Throsby, 2002; Vukonić, 2018; Yung, Yu \& Chan, 2013).

\section{Heritage buildings - symbols of cultural identity}

The built heritage includes symbolic meanings for local community members and visitors because, most of the time, significant historical events are associated with it. The built heritage is defined as one of the most important elements of authenticity and which reflects the identity of an urban centre (Kaymaz, 2013, p. 749) at local, regional or even national level, which also gives a sense of meaning of the place (Watson \& Waterson, 2010), known as genius loci; it "can be seen as a means to establishing a sense of identity and belonging" (KepczynskaWalczak \& Walczak, 2015, p. 2). Built space is an expression of culture in material form (UNDESA, 2012). Elements such as museums, palaces, temples, opera houses or streets and neighbourhoods can become symbols of cultural identity.

Cultural identity is expressed in architecture inside and further than the national state (Delanty \& Jones, 2002, quoted by Mahgoub, 2007) in that it creates uniqueness and local identity in an 
internationally competitive environment (Mahgoub, 2007). The cultural identity manifests itself in various forms and should not be perceived as a fixed and stable condition (Leach, 2003, quoted by Mahgoub, 2007). Cultural identity can be expressed by elements of traditional architecture, considering that its sources are derived from the past (Mahgoub, 2007). There are also opinions that the cultural identity can be expressed by the entire structure of the city, namely the character of a city conferred "by the sum of its multiple and fragmented interrelationships in the space between the buildings themselves, the social mix of people, its activities and events and the wider geographical framework of the city" (Silva, 2001, quoted by Mahgoub, 2007, p. 181).

Among the historical monuments of a city, iconic buildings have the greatest role in building the urban identity (Elhagla, Nassar \& Ragheb, 2020; Mohammad et al., 2020; Yalçinkaya, 2020). Iconic is derived from the ancient Greek word eikõn, which means "likeness, image, portrait" (Pipinis, 2014, p. 435), meaning to be found also in semiotics: "a sign that carries resemblance to its referent" (Encyclopaedia Britannica, 2013, quoted by Pipinis, 2014, pp. 435436). In vernacular, it covers a much wider range of meanings - "a legend, a role model, a superstar, the best example of something, an important and enduring symbol, an object of great attention and devotion, a religious painting, a pictogram in computer interface" (Pipinis, 2014, p. 436). These are aesthetic buildings with their own historical and cultural values (Watson \& Waterson, 2010; Elhagla, Nassar \& Ragheb, 2020; Uluğ, 2020).

The location of iconic buildings, carefully chosen, for strategic purposes, generates interactions frequently (e.g. active participation of the arts community) (Elhagla, Nassar \& Ragheb, 2020), increasing the popularity of the historical urban fabric in which they are located (Yalçinkaya, 2020). Iconic buildings are individualized through determined and conventional representative cultural codes (Watson \& Waterson, 2010), incorporated into the specific message associated with the edifice (Yildiz, 2018, quoted by Elhagla, Nassar \& Ragheb, 2020; Uluğ, 2020). At the same time, these constructions are individualized by unique characteristics that highlight the ir materiality: design, size, visual appearance, urban pattern or architectural style (Davarpanah, 2012, quoted by Elhagla, Nassar \& Ragheb, 2020, p. 803). Iconic buildings are primarily constructed to be visually appealing before being used with the established function (Elhagla, Nassar \& Ragheb, 2020).

\section{Representation of heritage buildings: promotion and decoding of symbols}

The elements of material cultural heritage have been represented in picture postcards for a larger public since the second half of the nineteenth century (Mârza, 2018). Thus, historical images have become not only a tool for promotion, but also a means of understanding cultural buildings and sites (Watson \& Waterton, 2010). The materiality of cultural heritage justifies the classification and aestheticization of objects, their disclosure and display, having associated economic as well as cultural value and, crucially, it allows the selection of what is meant to be seen. Visuality is a tool that enables the reading of the history of architectural monuments (Watson \& Waterton, 2010) through important cultural references like nationality, identity and social structure that are encrypted in the materiality of monuments and then projected to the general public (Kirshenblatt-Gimblett, 1998, quoted by Watson \& Waterton, 2010). The visuality also expresses the tourist significance of the heritage elements, taking various forms (tourist guides, brochures, postcards, websites), being labelled and selected among the represented objects (Watson \& Watson, 2010, p. 87). 
Once assimilated by society, monuments become an essential component of the "scopic regime," a term coined by Metz (1977) to describe the object "reality" of cinema (Watson \& Waterton, 2010, p. 87) and borrowed by Martin Jay $(1988,1996)$ "to define the wider social environment in which visual conventions have beenestablished" (Watson \& Waterton, 2010, p. 87).

The analysis of historical monuments is also made from the perspective of the message encapsulated in the object and transmitted to the public. In time, the object remains the same, while the message can be changed (Kepczynska-Walczak \& Walczak, 2015, p. 2) under the influence of political factors. Postcards could be an effective tool for shaping the public or official discourse (Mareci-Sobol \& Purici, 2020, p. 93). People perceived picture postcards at different levels and planes (Kepczynska-Walczak \& Walczak, 2015, p. 2).

The aim of this study is to highlight the socio-cultural evolution of the Romanian Athenaeum, using visual imagery as research material and visual analysis as a method for interpretation. The analysis of postcards from various historical periods, in which the Romanian Athenaeum is represented, is focused on deciphering the transmitted symbols, considering the in flue nce of social, cultural, and political factors. Based on the detailed analysis of the historical illustrations, the reconfiguration of the area adjacent to the Athenaeum was also highlighted.

\section{Romanian Athenaeum as a case study - symbol edifice of national culture}

The Romanian Athenaeum was built in a political climate of stability, out of a priority need to develop the Romanian culture which lacked a prestigious cultural institution to host important cultural activities. The Athenaeum was built (1886-1888) in the manner of literary or scientific societies of the first half of the nineteenth century, called "Atheneum," created within academies in various European cities (Lyon, Marseille, France) (in Belgium, the word Athenaeum also means secondary school; Adamescu, 1931, p. 138); in Italy, it is equivalent to university) (Balaci et al., 2007, p. 89).

Constantin Esarcu had the initiative to build a "palace of cults and arts," where the general public had access to various cultural activities (concerts, conferences, exhibitions, library, art gallery), which were joined by prominent personalities of the Romanian society, considered the founding members (Theodor Aman, Nicolae Bibescu, Ion C. Brătianu, Grigore Cantacuzino, Bogdan P. Hașdeu, Mihail Kogălniceanu, Emanoil Krețulescu, Nicolae Krețulescu, Alexandru Lahovari, Matei Millo, Alexandru Odobescu, Gh. Tătărăscu, Vasile A. Urechia, Eduard Wachmann, etc.) (Adamescu, 1931, pp. 139-140).

Esarcu thought of the Athenaeum as a cultural institution of national importance and with an imposing architecture, which required very large funds for its construction. In addition to the amount allocated by the mayor's office, a public subscription was made between 1885 and 1886, under the well-known phrase "Daţi un leu pentru Ateneu" ["Give a Leu for the Athenaeum"], organized in the form of a lottery in which 500,000 tickets (one Leu each) were sold. Among the people who made significant donations were King Carol I, Count Scarlat Rosetti, who offered by will his entire fortune to the Athenaeum (financial fund, real estate, book fund); Constantin Esarcu left his entire fortune to the Athenaeum, by will (furniture fund, annuity titles), Emil Porumbaru donated half of his library to the Romanian Athenaeum) (Adamescu, 1931, p. 150).

Regarding the location, C. Esarcu was concerned about finding a central location within the capital city (initially, there were two proposals near Cișmigiu Garden and at the border between Academiei Boulevard and Colței Street). Subsequently, in 1886, the Romanian 
Athenaeum Society was recognized as a legal entity and, for this quality, it received by law a piece of land, provided that the work of the cultural institution began within three years. The land belonged to Văcărescu family. On this land, a church was built, donated by General Mihai Cantacuzino to the Bishopric of Râmnicu (Vâlcea County). In time, the church entered a state of advanced degradation, which led to its demolition, and, on that land, there was arranged a garden completed in 1872, called the Episcopal Garden. In 1888, after the inauguration of the Athenaeum, the garden was incorporated into it (Sârbu, 2010). In 1886, the construction of the Athenaeum building began according to the plan of the French architect Albert Galleron, assisted by a technical commission composed of Romanian architects and engineers (Băicoianu Constantin, Grigore Cerchez, Ion Mincu, Ion Gr. Cantacuzino) (Constantinescu, 1989).

The Palace of the Athenaeum was built on the foundation of a circular circus manege, which the Romanian Equestrian Society had started without being able to finish it. The French architect used the foundation of the circus manege and, therefore, the shape of the Athenaeum building was circular, suitable for a concert hall.

The Romanian Athenaeum was built in neoclassical style, with numerous decorative elements, typical of French architecture, but it also has the characteristics of the eclectic style (Constantinescu, 1989; Sârbu, 2010). From the portico, the entrance to the vestibule is made through three wooden doors. Above the doors, there are five mosaic medallions representing Alexander the Good, Neagoe Basarab, Vasile Lupu, King Carol I and Matthew Basarab, made by the painter Costin Petrescu (Cercel, 2012) (Figure 1).

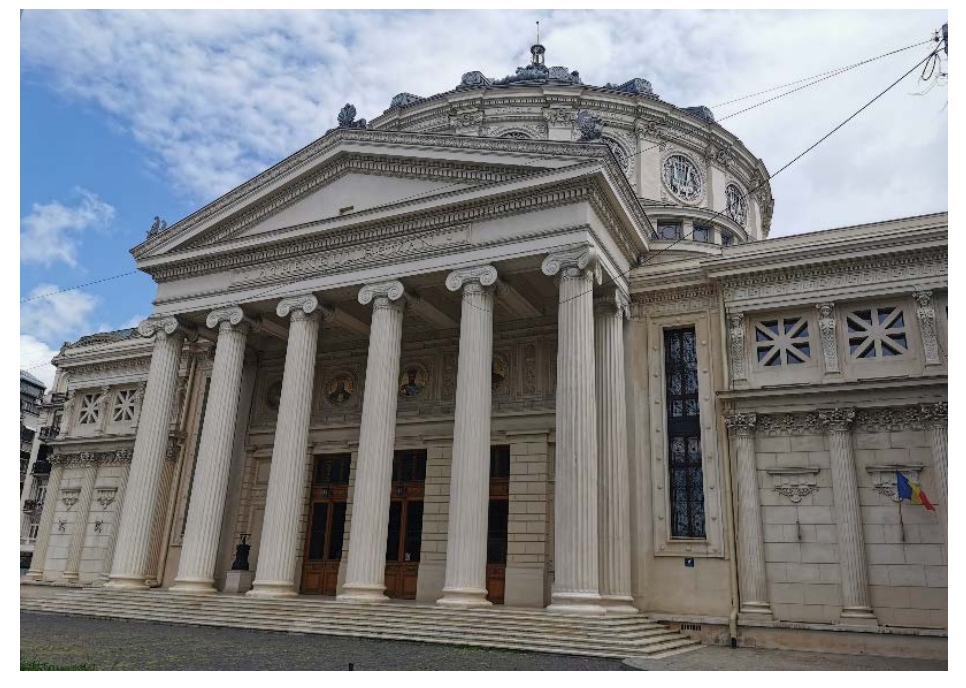

Figure 1: The main façade of the Romanian Athenaeum Source: photograph by F.-C. Merciu (June 2020)

The architect Galleron thought of the performance hall to be built upstairs, and, on the ground floor, to be arranged a large vestibule. Access to the playhouse is provided by four baroque spiral stairs, made of Carrara marble. The stairs end on the middle floor with a balcony that provides the access to the hall and the annexes (offices, rehearsal rooms, soloist booths, conductor). In the impressive lobby on the ground floor, there are twelve Doric columns, arranged in a circle, which support the central hall (Figure 2). 


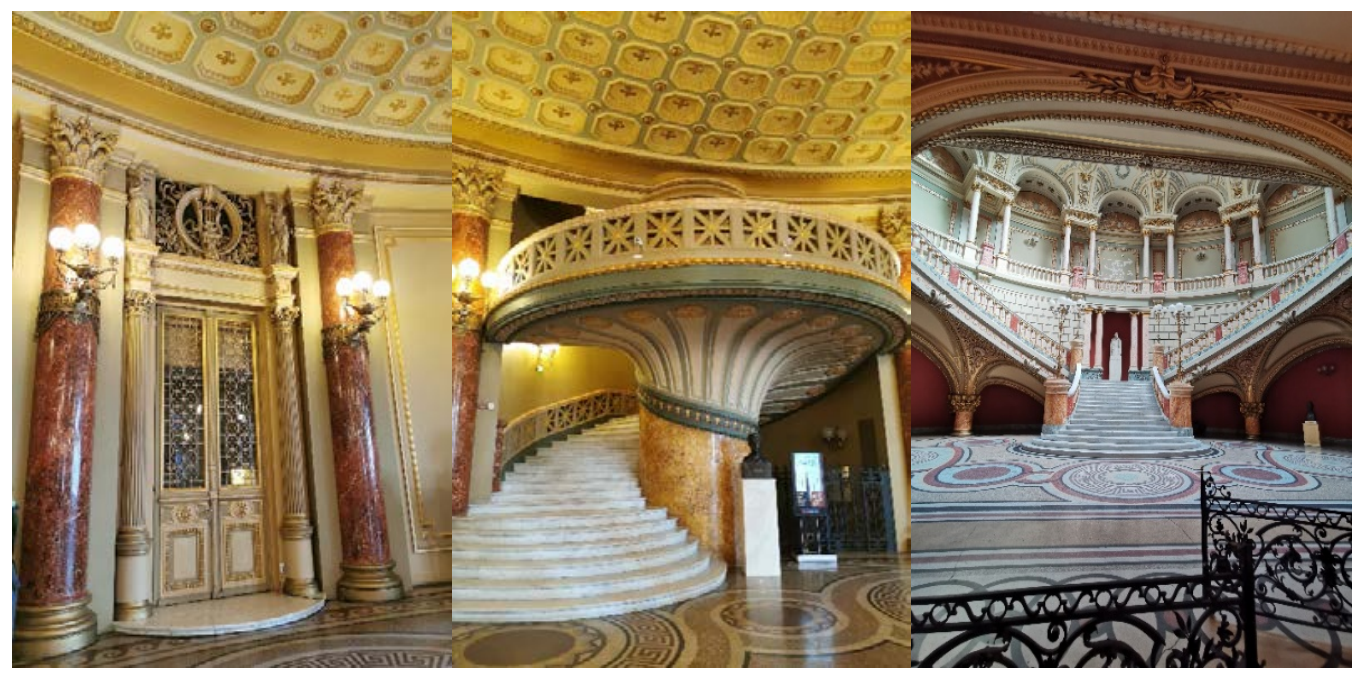

Figure 2: The monumental entrance of the Romanian Athenaeum Source: photographs by F.-C. Merciu (February 2020)

In front of the vestibule, the architect Galleron designed a monumental entrance whose façade is inspired by the temple of Erechteion in Athens: rectangular pediment supported by six frontal and two lateral ionic columns; the sides of the entrance feature have decorations after the Sibyl temple at Tivoli (Adamescu, 1931, p. 144) (Figure 1).

The roof is a huge dome created on an iron structure, according to the plans of the German architect Schwalbach (Adamescu, 1931; Constantinescu, 1989), who also supervised the installation (Constantinescu, 1989). Through its baroque architecture, the dome imposes its e If as a central element of the construction, having a height of $13 \mathrm{~m}$ (Constantinescu, 1989). The option to use the metal structure of the dome belonged to the French architect, to increase the strength of the building, being adapted to seismic risk, characteristic of Bucharest. The dome has twenty windows with lyres and wreaths. The zinc-covered dome ends with a tripod, after the model of the monument of Lysicrat in Athens, depicting the urn of the victors (Adamescu, 1931, p. 144; Constantinescu, 1989).

At the same time, the dome ensures the exceptional acoustics of the hall, an element that has placed the hall among the most successful of its kind in the world. The fresco in the concert hall, according to Al. Odobescu's conception as "a faerie of scenes from national history" (Cercel, 2012, p. 484), evokes the history of the Romanian people in 25 episodes, "in a continuous chain, like a historical film on a panoramic screen" (Cercel, 2012, p. 487). The mural painting was made between 1933 and 1937 by the painter Costin Petrescu, a specialist in fresco, originating from a family of church painters (Cercel, 2012, p. 485). C. Petrescu's work is the largest fresco with a historical theme in Romania (Cercel, 2012, p. 486).

In order to complete the construction of the building, it was necessary to borrow a sum of money from the Urban Land Loan in Bucharest. By a law issued in 1889, it was established the entry in the annual state budget of the amount for the payment of the instalments related to the credit. Thus, the Romanian Athenaeum Society will make the cultural building available to the Ministry of Public Instruction for international congresses, artistic, scientific, and literary gatherings, and for school solemnities (Adamescu, 1931, pp. 144-145). Therefore, to meet the need to host a variety of cultural activities, the original plan of the building was extended. Between 1893 and 1897, two double-level wings were built from the ministry's funds, located to the left and right of the main entrance, a space that currently runs on Nicolae Golescu 
Street. The two wings, built according to the plan of the architect Leonida Negrescu, include smaller rooms (for exhibitions), a public library and the State Art Gallery (Sârbu, 2010). In 1924, two movie theatres and two concentric circular exhibition halls were built in the basement; the library room was expanded, and the bookstore was created (Adamescu, 1931, p. 146).

The numerous technical improvements produced after the earthquake and bombings of 1944, at the end of the Second World War, the changes from 1966 and 1967 (introduction of air conditioning, restoration of the ceiling, redistribution of lodges, widening of the prosceniu ms) transformed the Romanian Athenaeum into a unique architectural complex in the centre of the capital city (Sârbu, 2010). Although the Athenaeum building was inaugurated in 1888, the concert hall was completed in 1889. The total height of the building is 41 meters, and the diameter is 29.16 meters (Constantinescu, 1989).

The Athenaeum Palace has hosted the symphonic concerts of the Romanian Philharmonic Society (founded in 1868 by Eduard Wachmann) (Adamescu, 1931; Sârbu, 2010), conferences, festivals (in the upper hall, the lower halls). From the early years, the Athenaeum Society organized art exhibitions: painting (since 1894, the official salons of fine arts), sculpture, or provided space for exhibitions of living artists. In 1927, a large retrospective exhibition of the Romanian artistic movement was held, hosting the works of past generations: Aman, Grigorescu, Lecca, Rosenthal, Pompilian, Stănciulescu, Tătărăscu, Andreescu, Henția, and Luchian (Adamescu, 1931, p. 148). Between 1919 and 1920, the building hosted the meetings of the Chamber of Deputies (Adamescu, 1931, p. 145). Since 2007, the Romanian Athenaeum has been included in the European Cultural Heritage due to its cultural, historical, and architectural importance.

\section{METHODOLOGY}

Postcards are used as research material in numerous socio-humanistic studies, dedicated to cultural heritage (Coskun, 2018; Grițco, 2007; Jones-Travers, 2018; Maroși, 2017; Watson \& Waterton, 2010; Mareci-Sabol \& Purici, 2020; Merciu et al., 2020), to the history of architecture (Marjanovic, 2004), to the history of regions and settlements (Mareci-Sohol \& Purici, 2020), in the analysis of natural and cultural landscapes (Chylińska, 2019; llovan \& Maroși, 2018; Ilovan, Ursu \& Dulamă, 2019), in tourism (Chylińska, 2019; Mellinger, 1994; Milman, 2012; Watson \& Waterton, 2010), in geomorphological and environmental studies (Sawyer \& Butler, 2006), etc.

Despite the fact that postcards are in general less requested documentary sources, recently the trend is to use them more and more (Mareci-Sabol \& Purici, 2020), especially to research the evolution of the society from a political, social, economic and cultural point of view (Gritco, 2007) or for understanding human relations (Mareci-Sabol \& Purici, 2020). In addition, picture postcards, especially historical ones, can offer information about the ideologies related to a certain place and a specific identity (llovan, 2019; llovan \& Maroși, 2018; Mareci-Sabol \& Purici, 2020, p. 93).

Moreover, the texts inserted on picture postcards by their publishers are especially important for researchers as postcards could also be analysed based on the semantic processes favoured by the interaction between visuality and textuality (Almasy, 2018, quoted by Mareci-Sabol \& Purici, 2020, p. 93). For example, linguistic elements may provide additional details about the 
subject represented: period, names of settlements written in various languages (Jaworski, 2010; llovan \& Maroși, 2018).

Visual imagery is the research material that can be processed through qualitative methods, because interpreting the provided information can be realised through discourse analys is and visual analysis (Doğan, 2019; Ilovan \& Maroși, 2018). Visual imagery is used in the analysis of cultural heritage elements by relating it to the socio-cultural context, while seeking to underline the aesthetic and inherent values of architectural monuments. Visual imagery is examined "as an essential part of the process by which cultural heritage is produced and which, in turn, allows visual culture to be 'read' as an identity narrative, politics and power" (Watson \& Waterton, 2010, p. 84). Visual analysis allows the construction of a critical discourse that enables the decoding of symbols and the identification of the narrative or narratives concerning heritage (Kirshenblatt-Gimblett, 1998; Hooper-Greenhill, 2000, quoted by Watson \& Waterton, 2010).

\section{Instruments of research}

The study was divided into two stages, following the methodological steps identified in other similar studies (llovan, 2019; llovan \& Maroși, 2018). In the first stage, a large number of picture postcards was identified, which due to the information they contained (postage stamp, address, image, subtitles, text, editor) (Rose, 2014, quoted by llovan \& Maroși, 2018) provided details significant for the interpretation of images. At the same time, the connection between the image and the viewer is important, because image interpretation is a highly interactive process and can be developed by referring to some elements in order to contextualize the meaning of picture postcards: the editor, the purpose for which they were edited, the audience.

The authors collected 103 old images (i.e. postcards, photographs) depicting the Athenaeum Palace and its garden. Picture postcards were collected through accessing the website of "George Enescu" Philharmonic or blogs that displayed historical images about the Romanian Athenaeum. We also used images from our personal collections. Some of the old postcards were identified in a private collection, which was published in the form of an album of postcards (Mărgărit, 2019), in which there were represented several symbolic buildings of Bucharest, including the Athenaeum. The authors selected the visual research material from various periods.

The process of selecting picture postcards is difficult because of the need to identify representative illustrative materials (Rose, 2014, quoted by llovan \& Maroși, 2018) for a certain object or process. That means that also our filter, of the authors of this article, was superimposed, during the selection process. The selection of postcards targeted, on the one hand, the most representative picture postcards for the evolution of the Romanian Athenaeum and its garden (due to the represented details), and, on the other hand, those that could provide as rich details as possible to allow an in-depth discourse analysis. For the selection of significant photographs, especially historical ones, Leary (1985), in a study developed for the United Nations Educational and Cultural Organization (UNESCO), established a series of criteria such as: age, quantity (often dismissed as a factor in appraising photographs because their volume is usually small), subject, and several others which are admittedly of unequal significance like uniqueness, identification (the presence of captions: publisher, subject, date, location, etc.); (technical) quality, accessibility, and photographer (pp. 41-62). 
In our study, these criteria were used to select representative visual imagery in order to identify the symbols associated with the Romanian Athenaeum promoted in the visual landscape characteristic of picture postcards for each historical period. For example, for most picture postcards from the late nineteenth century, the artistic value of representations of the Athenaeum and its garden is noticeable and correlated with the criterion of technical quality.

On the other hand, the selection of picture postcards from late nineteenth and early twentieth century focused on identifying and underlining the changes in the appearance of the Athenaeum and its garden, an action that was correlated with the main ideas disseminated in scientific texts used to document the history of the building and its garden. The documentation was used to contextualize the representations of the building's evolution (e.g. the August 1944 bombing that affects the resistance structure of the building) and that of its adjacent space. As the greatest dynamics of changes in the appearance of the adjace nt space was recorded until the beginning of the twentieth century, more postcards from the pre-war period were selected compared to the interwar one.

In the case of the illustrative material from the communist period, several symbolic elements of the socialist regime are represented next to the philharmonic. One can also recognise the transmission of some coded messages concerning the communist policy, which determined the selection of several picture postcards. At the same time, the higher number of picture postcards from the communist period was justified by the representation of the Athenaeum both as a main element and in collages with buildings constructed in the early twentieth century or with symbolic buildings of the socialist period.

After the selection of representative picture postcards, they must be connected to various social practices and systems, which provides a rich descriptive context and the meaning of postcards is partially acquired (Rose, 2014, quoted by llovan \& Maroși, 2018, p. 138). The full meaning is never achieved, because meaning is constructed not only by those who created the images, but also by the audience.

The old illustrations considered to be the most suggestive were ordered chronologically and selected to highlight the evolution of the cultural institution and the adjacent space (the square in front of the Athenaeum) in various periods, identifying the phases of postcard production: end of the nineteenth century (four postcards, the oldest one dating back to 1889, one year after the inauguration of the Athenaeum), the beginning of the twentieth century (four picture postcards, one periodical publication), interwar period (three) and communist periods (fourteen), the current period (after the 1990s: two).

Each postcard was analysed in detail, in several standardized fields, to identify various details (vegetation, view-orientation, buildings, people: clothing, activities), details also analysed in other studies (Jones-Travers, 2018; Maroşi, 2017). We used the method of comparison, by alternatively analysing old images and current photographs.

The documentation activity represented a distinct research stage that materialized by collecting data on the manner of constructing the building, its importance and role in the socio-cultural and economic context of the late nineteenth century Bucharest. The relation of the Athenaeum, in time, with the socio-cultural context and the most important socio-cultural events of the capital city was analysed in order to emphasize the importance of this building as a symbol of national and European culture. 


\section{RESULTS AND DISCUSSION}

As previously emphasized, the Athenaeum was conceived as a cultural institution with a significant role in revitalizing the cultural life of the capital city and, as a result, it was necessary to identify a location in the centre of Bucharest. During the $19^{\text {th }}$ century, Bucharest was characterized by a dynamic urban evolution (Merciu et al., 2018), marked by the construction around the medieval nucleus of new areas consisting of buildings with residential, administrative, and cultural function. In the context of the accelerated urban development of the capital city, the land on which the Athenaeum Palace was located will undergo a series of transformations starting with the mid-19 ${ }^{\text {th }}$ century. The land belonged to lanache Văcărescu. At the beginning of the $17^{\text {th }}$ century, it was on the northern periphery of the central area of Bucharest, located near the third barrier / sentinel, called Podu Mogoșoaiei (Pappasoglu, 1891, p. 61), a barrier that separated the central from its peripheral area. The name of the land, "the Văcărești Orchard," indicates an agricultural use of the land, specific to a peripheral area adjacent to cities.

After the land was taken over by lanache Văcărescu's heirs, through its parcelling, it would undergo significant transformations: lanache Văcărescu's daughter, llinca, married the boyar Mihai Cantacuzino. After her death, her husband took over the property and bought other pieces of land, around the orchard, with the intention of building a church, the Metochion of the Bishopric of Râmnicu Vâlcea. Later, when the church became a ruin, it was demolished and later a modern garden was arranged, completed in 1872. It was called the Episcopal Garden (Pappasoglu, 1891, p. 61).

On the place of the church altar, a stone column was erected in 1888, with an eagle with outstretched wings and a cross on its head, which can be seen on the historical illustrations in which the Athenaeum is represented (Figure $3 a, b, c, d$ ).

The garden, which occupied a large surface $(5,000 \mathrm{sqm})$, will be integrated into the central area of Bucharest, due to urban expansion, and will be gradually surrounded by more constructions. Nearby, there were the houses of personalities from the political and cultural life: the sumptuous house of the steward Dinicu Golescu, where the ruler Alexandru loan Cuza also lived between 1859 and 1866; from May 10, 1866, the house became the residence of Prince Carol I, and was later demolished and the Royal Palace was built in 1937 (Ipate, 2006); the house of the deputy Nicolae Cesianu located on Clemenței street no. 5 (today C. A. Rosetti), which adjoins the properties belonging to $\mathrm{C}$. Boierescu (located to the west, later the land being occupied by the famous restaurant "Cina" / current name "Il Calcio"), N. Fotino, etc. (Duțu, 2001, p. 239). The landscape arrangement of the garden is special, being made by Alexis Godillot, a fact that stands out from the arrangement of vegetation and alleys paved with stone (Figure $1 \mathrm{a}, \mathrm{b}$ ). Initially, the access to the garden was made from Podu Mogoșoaiei / Calea Victoriei, with the entrance on the southern side (Figure 3).

Subsequently, the Romanian Athenaeum Society receives the agreement to build the palace on the site abandoned by the Romanian Equestrian Society, which is awarded compensation. The construction of the Romanian Athenaeum generated the reduction of the surface of the Episcopal Garden, which, in 1888, was incorporated into it, from which it was initially separated. Since then, it is known as the Athenaeum Garden. The access to the garden on its southern side, in mid-nineteenth century, also represented the advantage of arranging, on the site on which the church was built, an alley that ensured the access to the Athenaeum Palace (Figure $3 \mathrm{a}, \mathrm{b}$ ). 

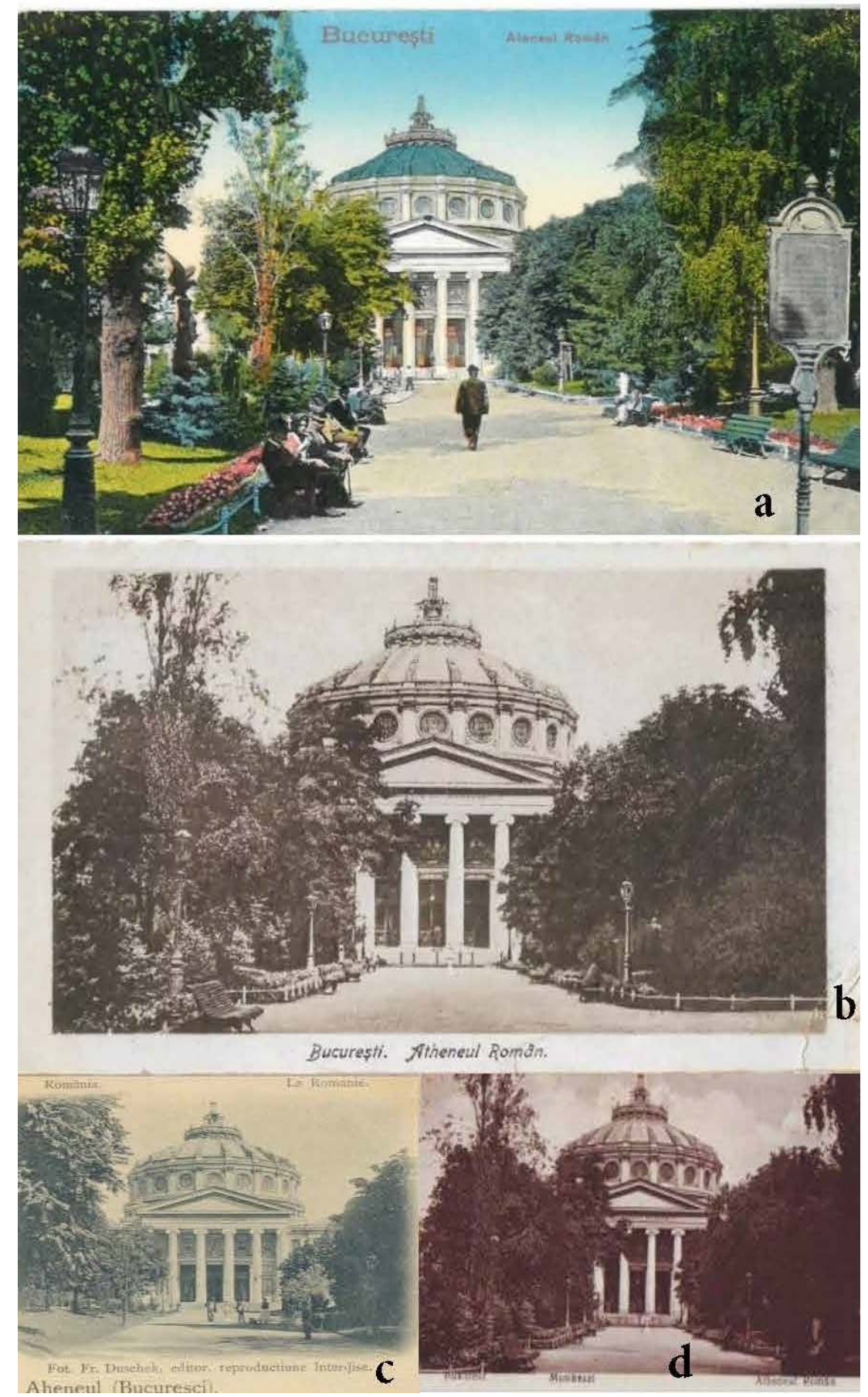

Figure 3: The Romanian Athenaeum (the end of the $19^{\text {th }}$ century) Source: $a$ and $b$ from the personal collection of F.-C. Merciu c and d from Turist în București, 2013

The name of the publisher is also indicated on one of the old postcards (Figure $3 \mathrm{c}$ ): Franz Duschek, a famous Czech photographer who opened a photography studio in Strada Nouă (today Edgar Quinet), the brother-in-law of Carol Popp of Szathmari, one of the most appreciated photographers of art in Bucharest. In the course of time, the photographer changed several locations of his studio. He received the title of photographer of the Royal 
Court in 1881 (Zamani, 2015), aspect that also appeared in an advertisement of his photographic workshop (Figure 4, left); on the poster, it is mentioned the location of his workshop (Franklin Street, opposite to the Episcopal Garden), located very close to the place where the Athenaeum was built later (Figure 4, left). He also made postcards in a way that allowed the observation of architectural details or of the urban social life.
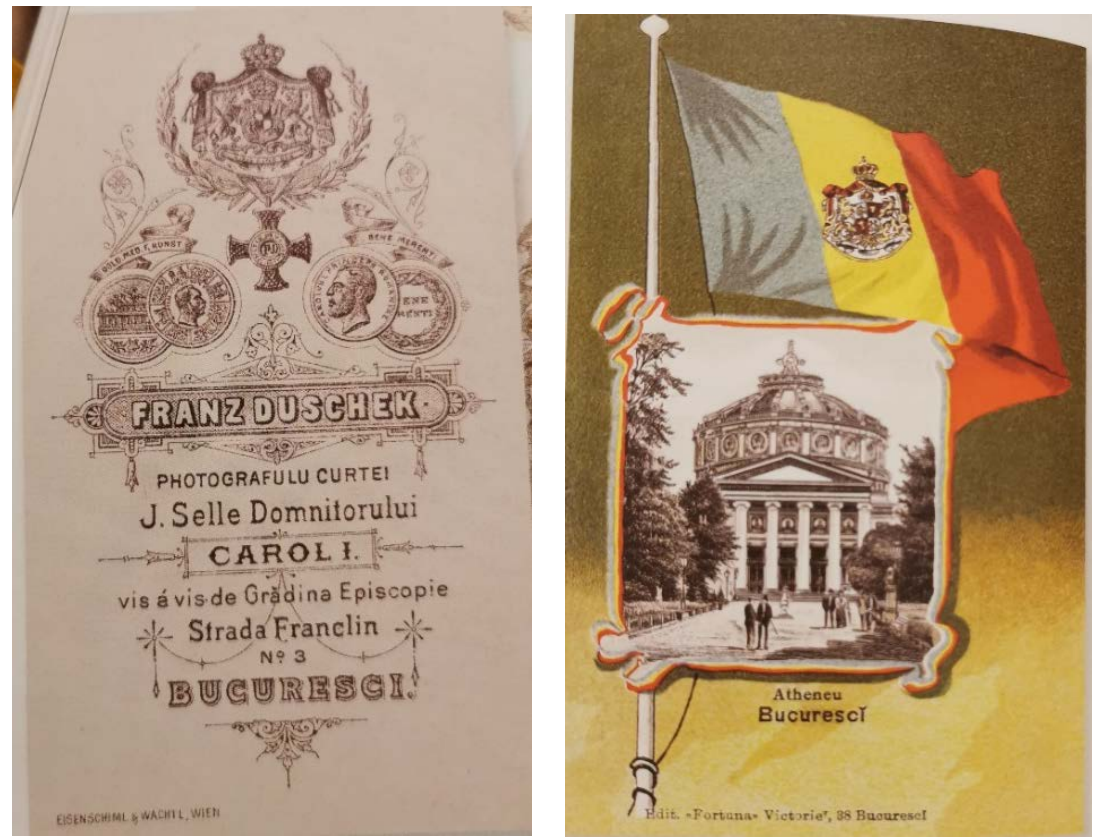

Figure 4: (left) Advertisement poster of Franz Duschek's photo studio in which it is mentioned that he has the title of photographer of the Royal Court of Romania (dating: beginning of the $19^{\text {th }}$ century); (right) The cover of a publication focused on the description of the Romanian

Athenaeum on which there is a picture postcard with the Philharmonic and the Flag of Romania during the royalty (dating: beginning of the $20^{\text {th }}$ century)

Source: S. Mărgărit (2019)

On the cover of the book, suggestively titled "Athenaeum," with a description of the philharmonic, edited at the beginning of the twentieth century, is selected a picture postcard in which, the Athenaeum is represented next to the Romanian flag from the period of royalty (Figure 4, right). This representation draws our attention to the importance attached to the Romanian Athenaeum by the members of the royal family. Supporting this idea, it can be mentioned that the election of the King Carol I of Romania was marked by a conference organized on April 9, 1906, at the Romanian Athenaeum (Onciul, 1906). This justifies the fact that the Athenaeum was already a cultural building symbol of national importance.

The historical postcards also represent elements of urban social life (i.e. the Athenaeum Garden was an animated space due to its aesthetics, with an obvious recreational character: the presence of people walking or resting on benches). The recreational character of the Athenaeum Garden is captured in several postcards from the early twentieth centu ry, such as those in the collection of historical postcards edited by Sorin Mărgărit (2019) (Figure 5). The postcards included in this album are artistically made, suggesting the aesthetics and architecture of the Athenaeum. The representation of people in these historical postcards provides additional details about the clothing characteristic of the Belle Époche, observing the influence of French fashion (Figure 5a). 

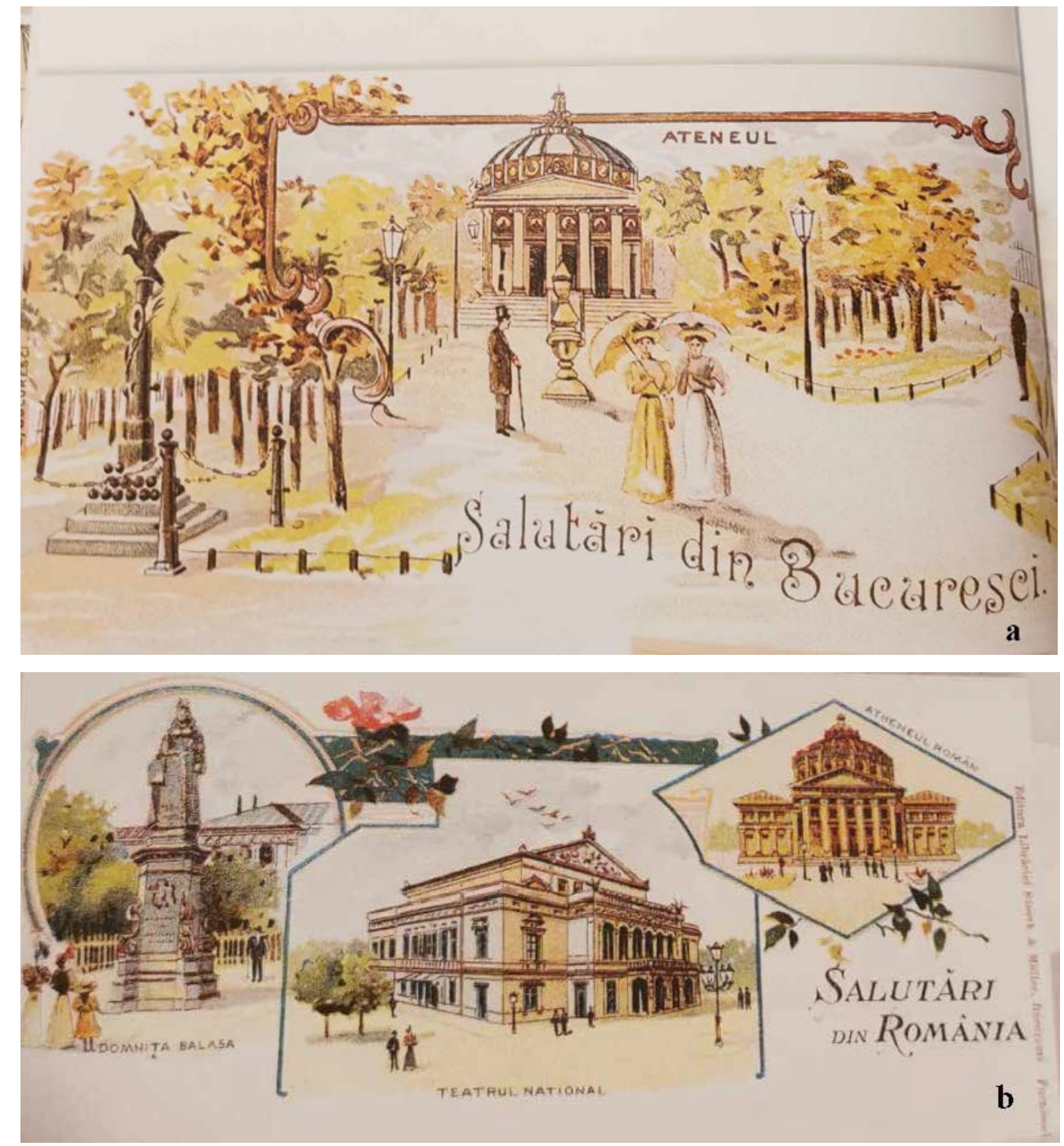

Figure 5: (a) The Athenaeum and its garden as recreational space; (b) The Athenaeum illustrated in a collage (dating: beginning of the $20^{\text {th }}$ century): (left) Statue of Miss Bălașa, (middle) The National Theatre, (right) The Romanian Athenaeum

Source: S. Mărgărit (2019)

The Romanian Athenaeum is also represented in periodicals published at the beginning of twentieth century (Figure 6). Due to its cultural importance, the Athenaeum is represented, in the form of a pencil sketch, in the headline of the periodical: "Arts Gazette: Theatre, Music, Painting, Sculpture, Architecture, Gymnastics, Dance," in the issues of 1903 and 1904. This periodical was published between October 1902 and May 1904, in Bucharest (Hodoș \& Sadi Ionescu, 1913, p. 281), being a tool of promoting arts in the capital city. 


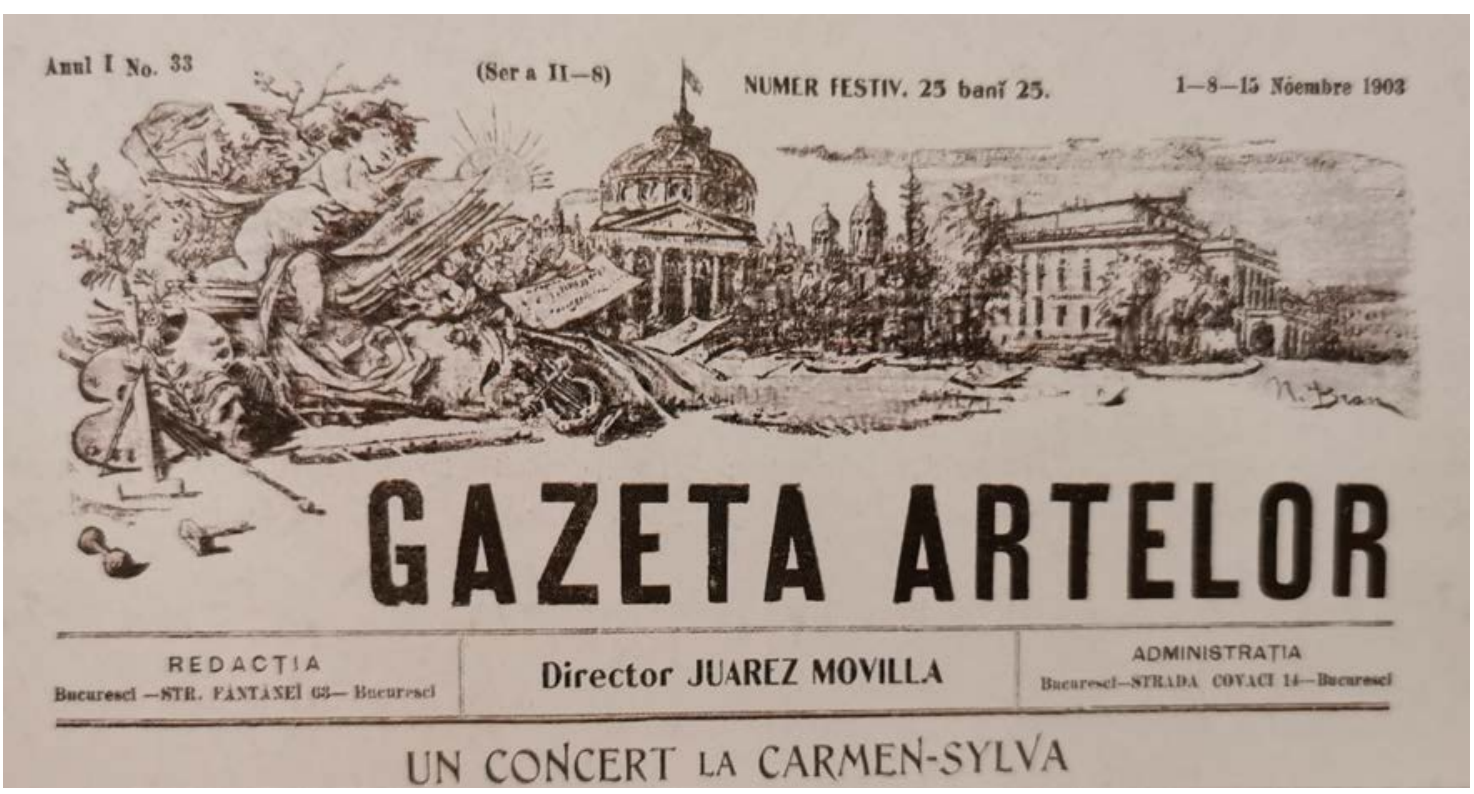

Figure 6: The periodical "Arts Gazette. Theatre, Music, Painting, Sculpture, Architecture, Gymnastics, Dance" in whose header the Athenaeum is represented (1903)

Source: S. Mărgărit (2019)

At the beginning of the twentieth century, the garden underwent a series of changes: the access to the Athenaeum through the sides was created, so that the alley arranged in the middle of the garden was grassed. Busts of some of the most important personalities of the Romanian culture were placed on the side alleys, some of them being among the founding members of the Athenaeum (Constantin Esarcu, Mihai Eminescu, Mihail Kogălniceanu, C.A. Rosetti, V. A. Urechia, lenăchiță Văcărescu, Traian Demetresc, Gh. Dem. Teodorescu, Gavriil Muzicescu and others). The statues can be seen in the postcards printed at the middle of the twentieth century (Figure 7).

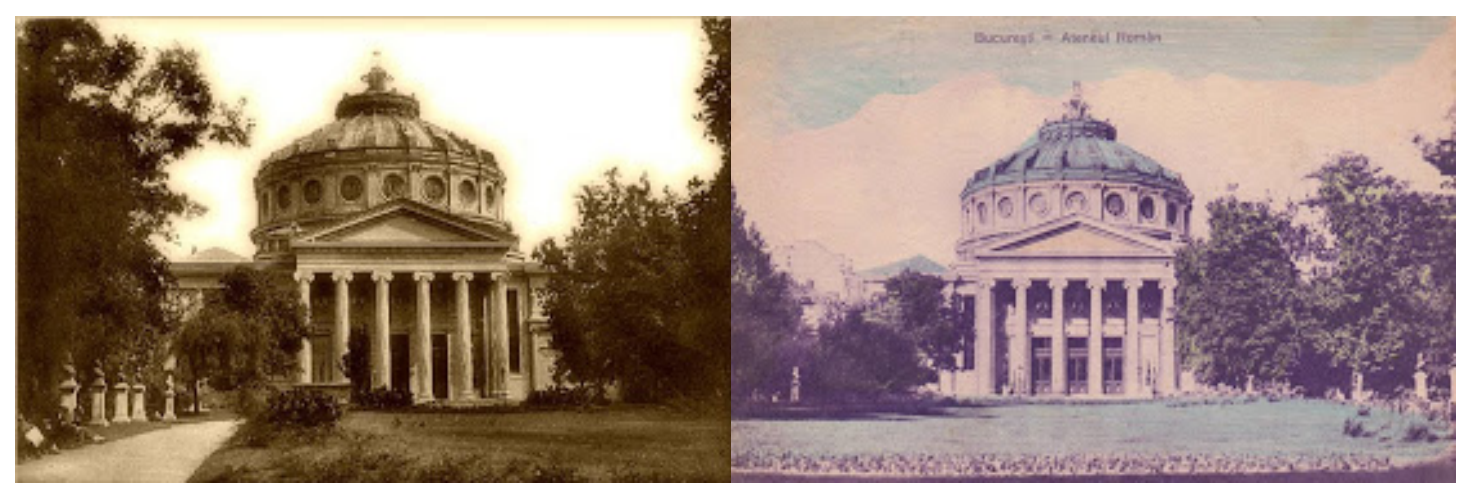

Figure 7: (left) The Romanian Athenaeum (1927); (right) The Romanian Athenaeum (1931) 


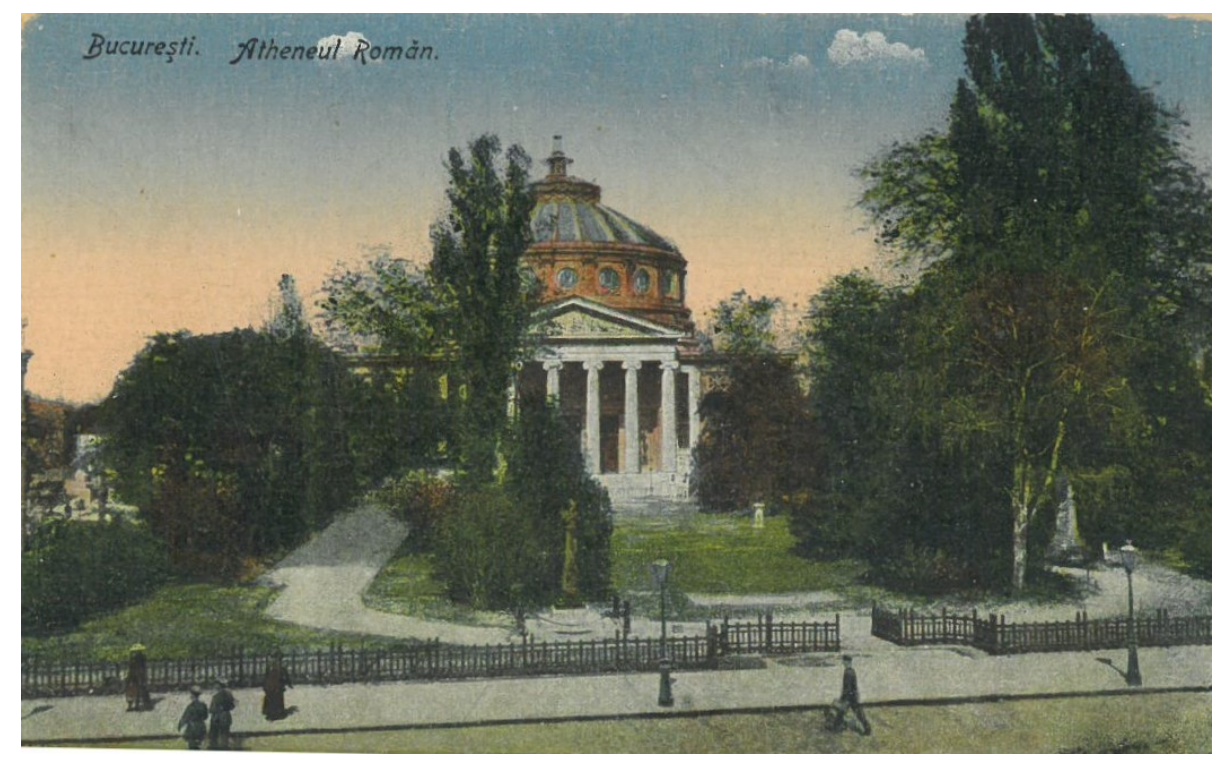

Figure 8: The Romanian Athenaeum (approximate dating: beginning of the $20^{\text {th }}$ century) Source: personal collection of F.-C. Merciu

In the interwar period, there are new changes in the appearance of the garden: most of the vegetation was cleared. In front of the Athenaeum was placed the statue "Runners" (or "Towards the Ideal"), made by the sculptor Alfred Boucher, in 1913 (Figure 9).

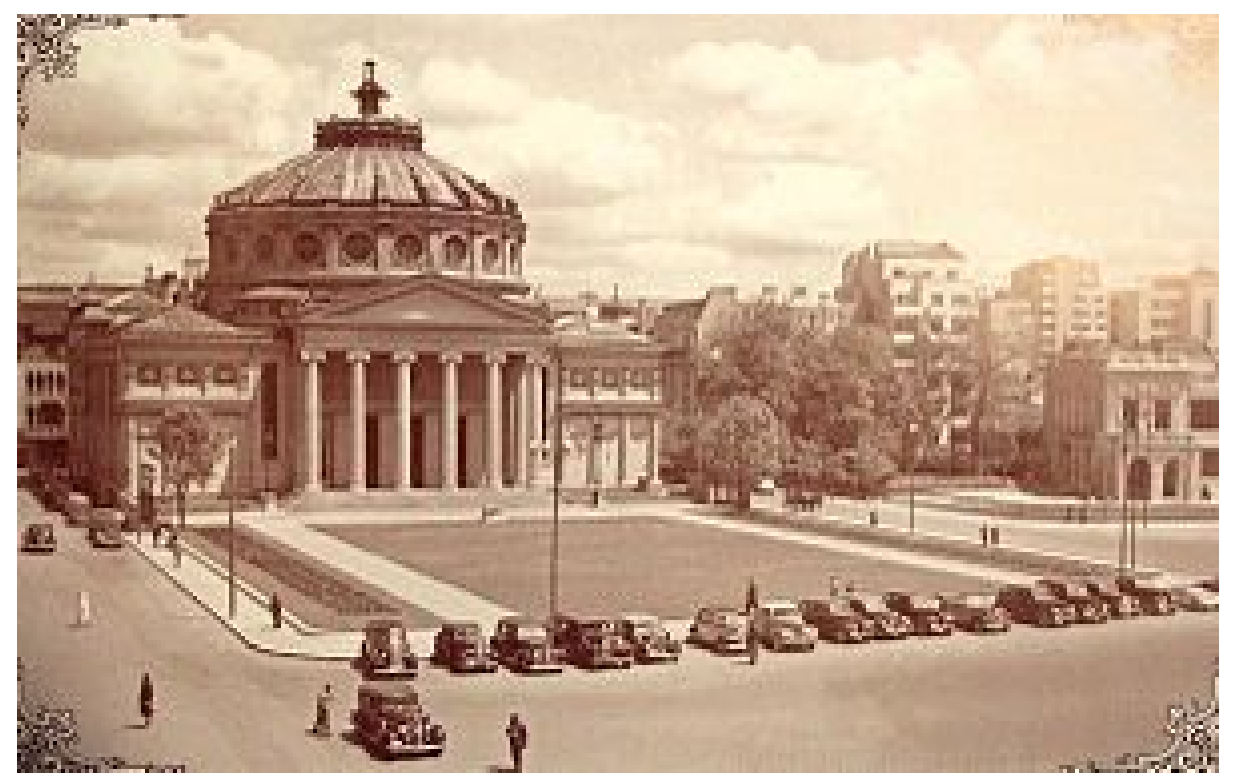

Figure 9: The Romanian Athenaeum - the inter-war period Source: Filitti, 2016

In 1944, the Athenaeum was bombed by the German army, the palace being severely damaged, which required restoration works (Figure 10). 


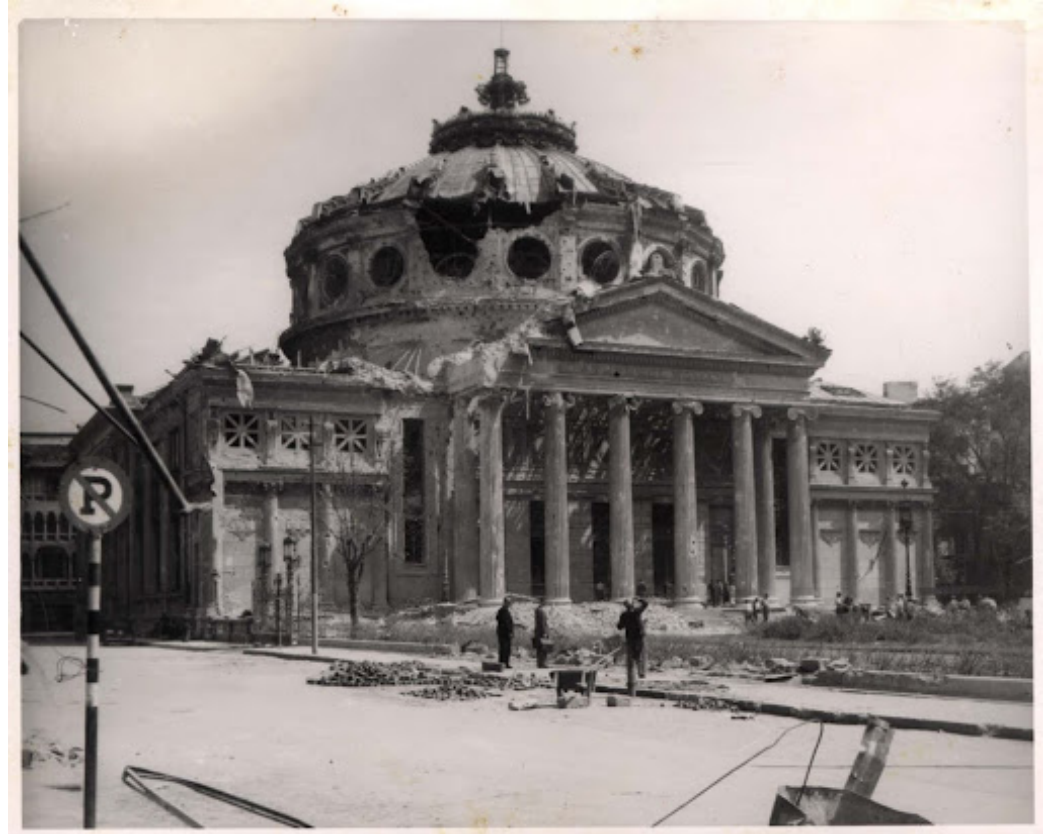

Figure 10: The Romanian Athenaeum affected by the German bombing - August 1944 Source: Filarmonica „George Enescu”, 2020

In 1950, the Athenaeum Garden underwent the last important transformations: all the statues were removed at the request of the Communist Party leaders, the alleys were rearranged, and the central part of the former garden was arranged as a rich green space adorned with rounds of flowers (Figure 11). Its surface will be reduced by creating a parking space on the side from the Royal Palace (Sârbu, 2010). At the end of the 1950s, the statue "Runners" was relocated on Calea Victoriei, close to the intersection with Amzei Market, where it is still today.

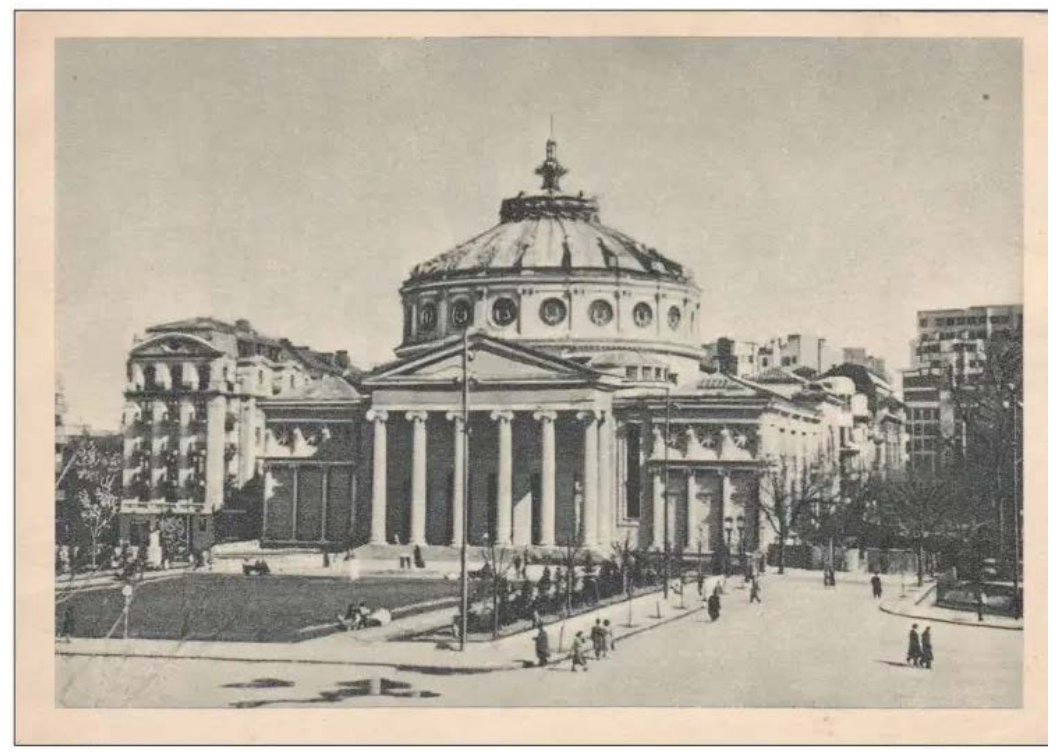

Figure 11: The Romanian Athenaeum (1957) 
The publishing of postcards, in which the Athenaeum was represented, marked a series of significant moments in the history of the Romanian Communist Party, such as the $20^{\text {th }}$ anniversary of the establishment of the Socialist Republic of Romania (1947-1967) (Figure 12). Such representations were propaganda means highlighting the continuity of the communist policy. This information was extracted following the detailed analysis of the elements on the picture postcard - on the stamp, it is written: "Anniversary of the Republic 1947-1967."

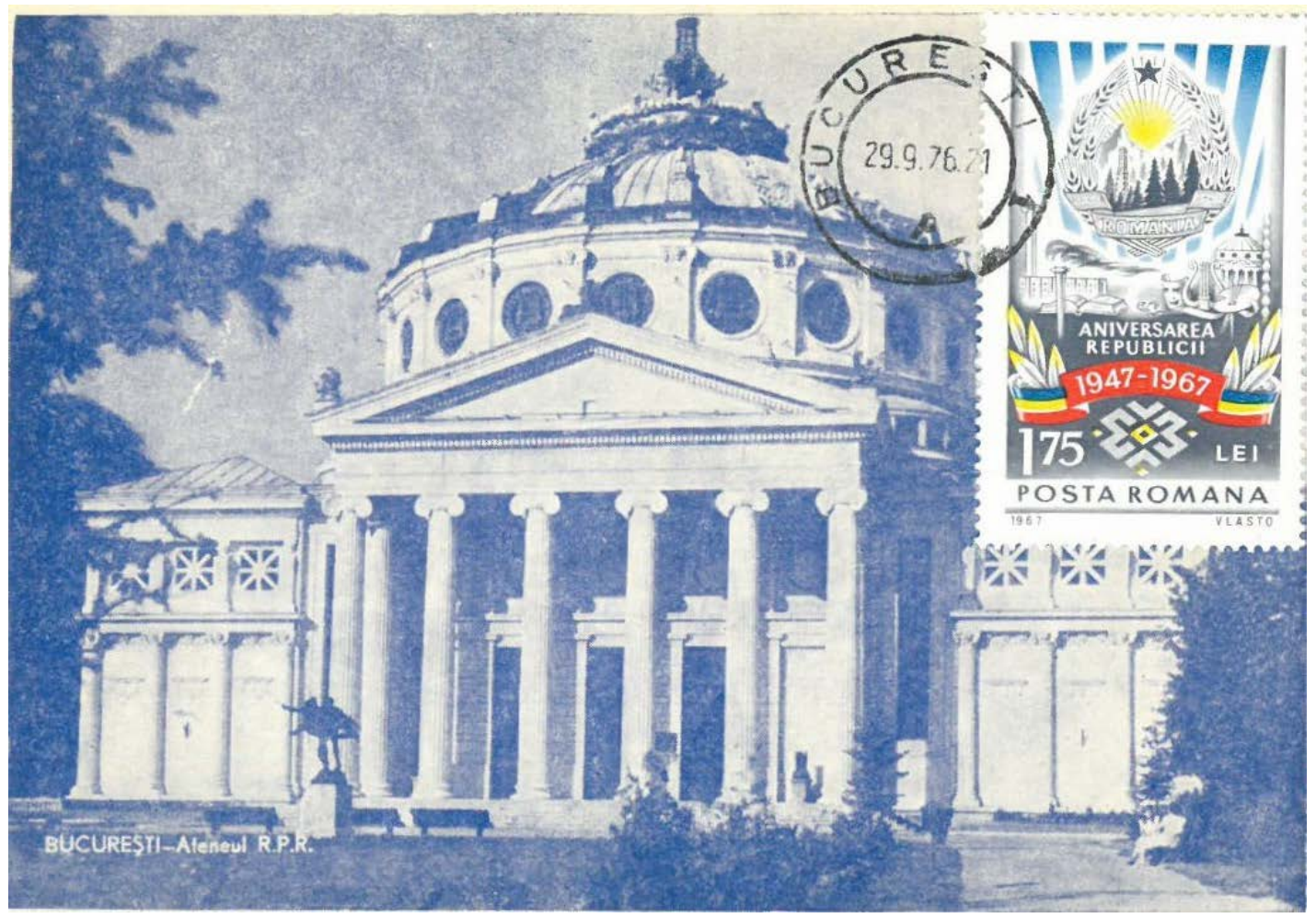

Figure 12: The Romanian Athenaeum represented in a postcard on the occasion of the $20^{\text {th }}$ anniversary since the creation of the Socialist Republic of Romania (1947-1967); this information is mentioned on the stamp

Source: personal collection of F.-C. Merciu

In 1965, the statue of the national poet, Mihai Eminescu, executed in bronze by sculptor Dumitru Anghel (Caloianu, Filip, 2009), is placed in front of the Athenaeum (Figure 14). During the communist period, one could notice an adequate care of the square in front of the Athenaeum, the frequent change of floral ornaments, which sometimes occupied almost its entire surface. During this period, numerous postcards were printed in which the Romanian Athenaeum was represented, either as a unique element (Figures 12, 13, 14), or next to other buildings, in the form of a collage (Figures 16, 17, 18, 19). Some postcards were published by the Tourist Office, which highlights the policy launched by the Communist Party to promote the cultural objectives of the capital city.

Figure 15 is a picture of the Athenaeum, taken recently, which shows some details about the landscaping of the square. Since the 1990s, shrub species have been planted on the sides of the square. In recent years, shrubs have been replaced by silver firs (seven on each side), having a double role: aesthetic and ecological, conifers being usually planted in urban green spaces to reduce the amount of emissions generated by congested car traffic. 


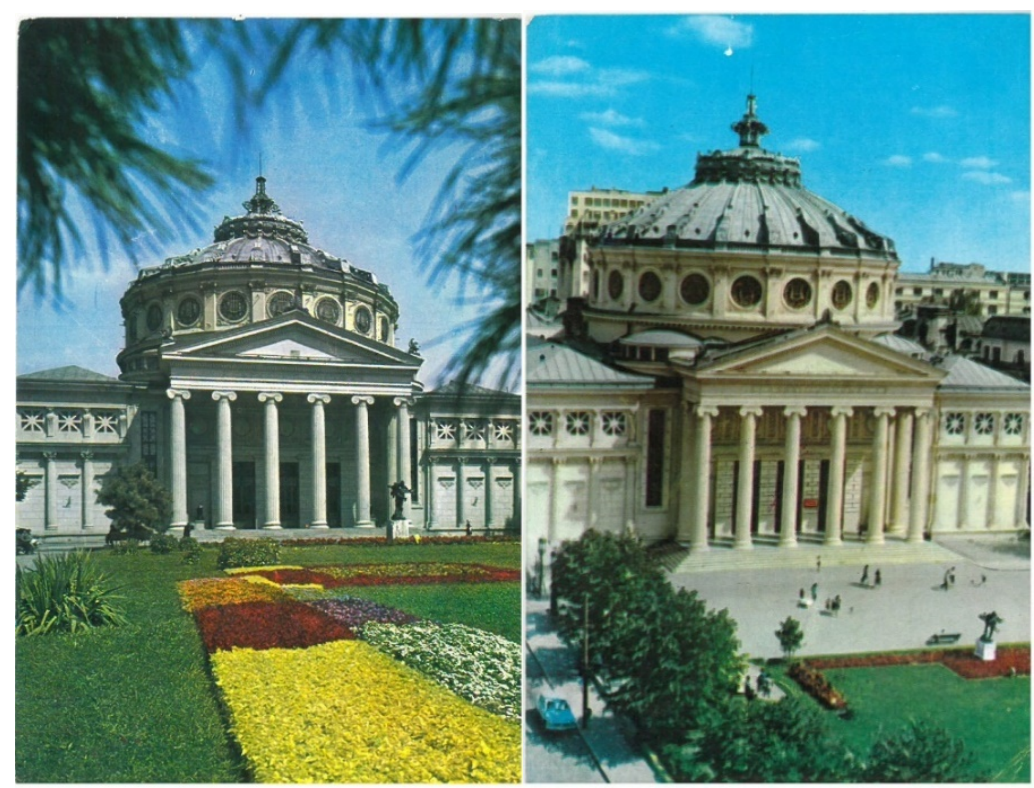

Figure 13: The Romanian Athenaeum represented in postcards published during the communist period, approximate dating: the 1950s, the estimation of the period being correlated with the presence of the statue "Runners"

Source: personal collection of F.-C. Merciu
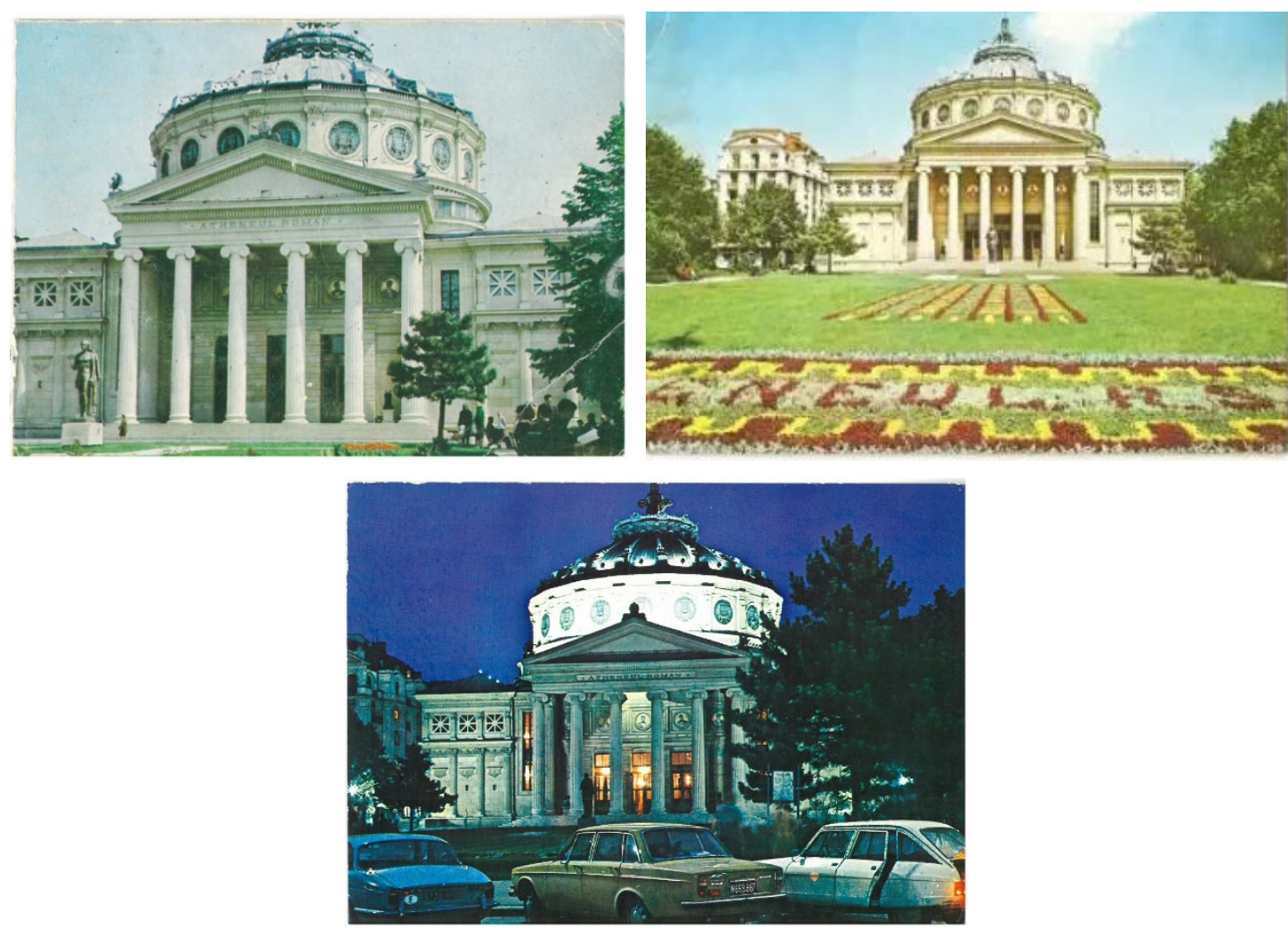

Figure 14: The Romanian Athenaeum, represented in various postcards, published during the communist period 


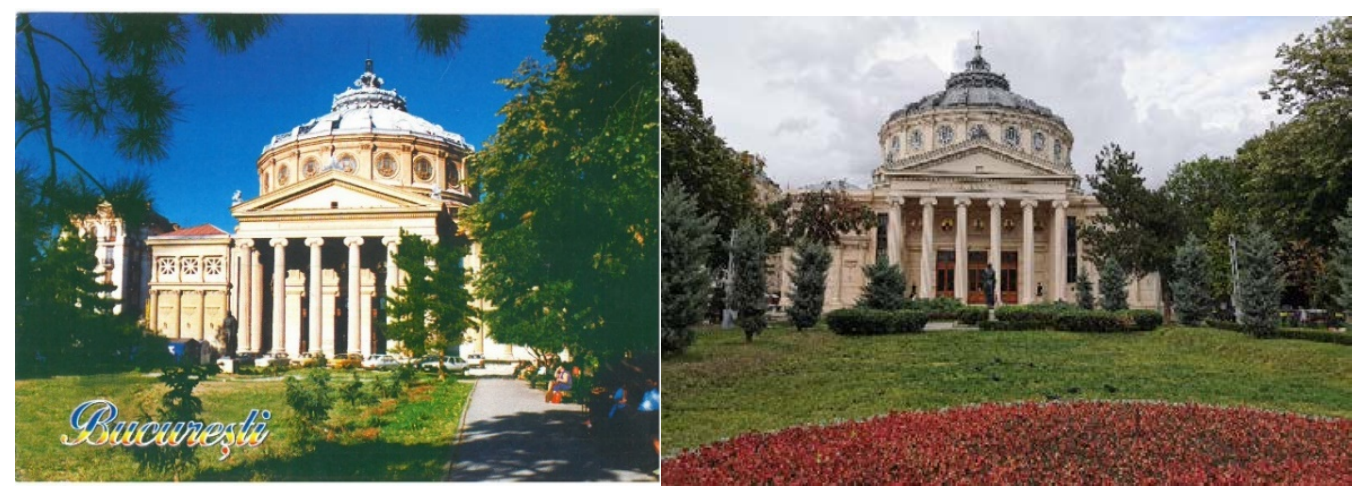

Figure 15: The Romanian Athenaeum in the 1990s (left) and 2019 (right)

Source: personal collection of F.-C. Merciu

Many of the buildings represented in collages next to the Romanian Athenaeum were not built during the communist period that aimed at the tourist promotion of Bucharest. These buildings are representative architectural elements for the capital city (e.g. The Military Circle, The Savings and Consignments House, Capșa Hotel, Athénée Palace Hilton Hotel) (Figure 16).

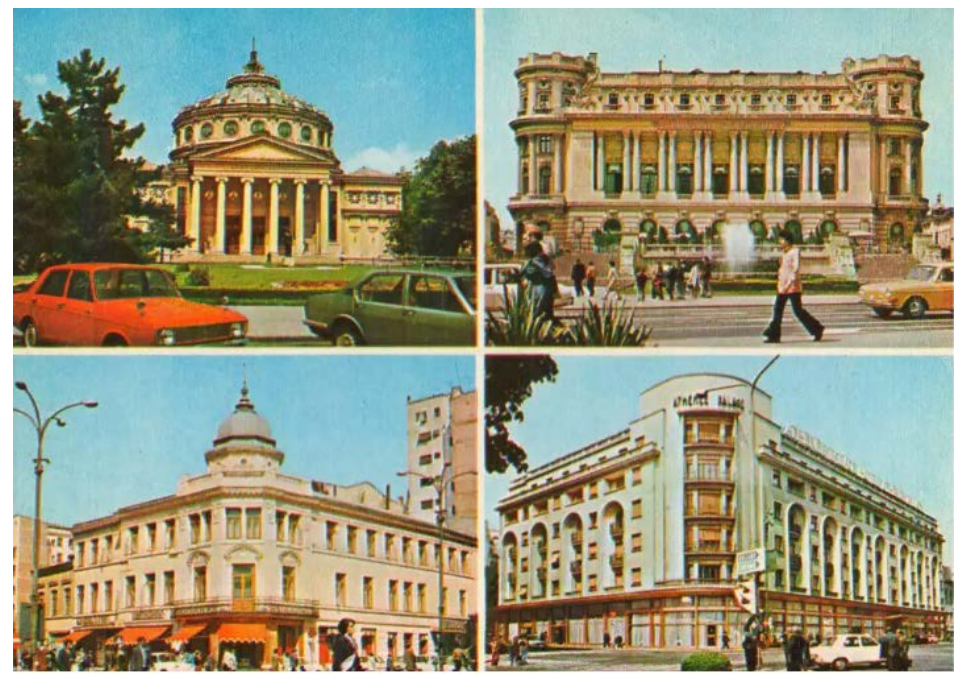

Figure 16: Collage postcard: (top left) The Athenaeum, (top right) The Military Circle, (bottom left) Capșa Hotel, (bottom right) Athénée Palace Hilton Hotel

Source: personal collection of F.-C. Merciu

In some postcards that include collages, there are other buildings considered symbols of Bucharest, built during the communist period, such as: Casa Scînteii [The House of Scinteia], the main printing house of the country during that period (Tulbure, 2013), whose name comes from the newspaper "Scînteia," the main instrument of written propaganda of the Romanian Communist Party (Cora, 2014); it is currently called the House of the Free Press (Figure 17); The Palace Hall (built between 1959 and 1960, during the regime of Gheorghe Gheorghiu-Dej, made to host shows and congresses of the Romanian Communist Party) (Figure 18); The State Circus (built in 1960) (Figure 19). 


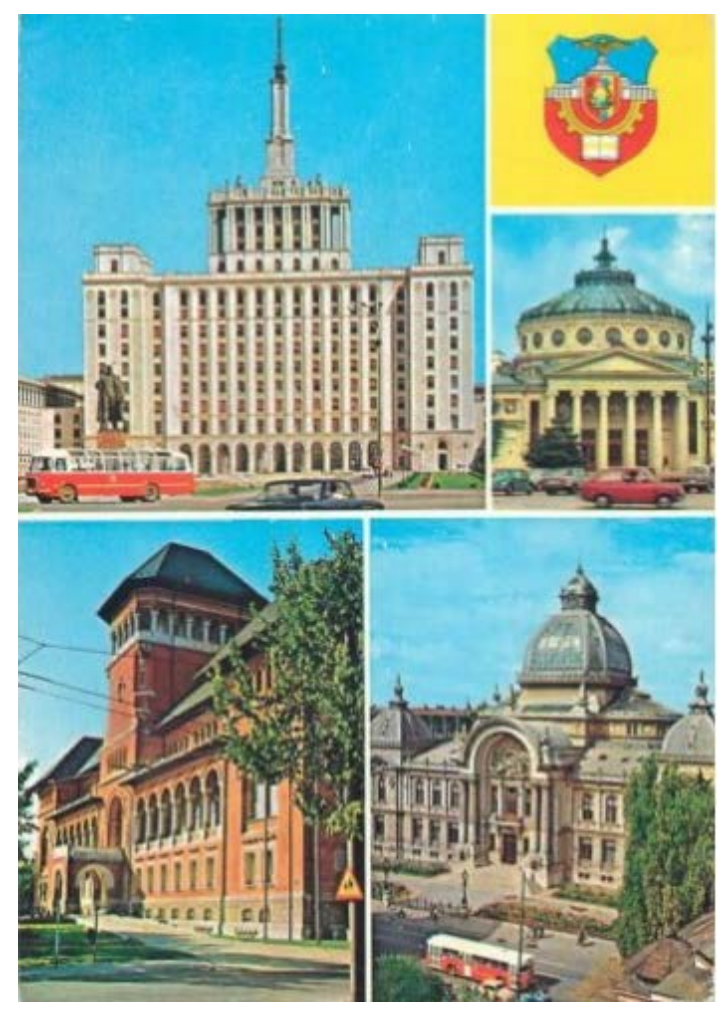

Figure 17: Collage postcard with (top left) Casa Scînteii, (top right) The Atheneum, (lower left)

The History Museum of the Romanian Communist Party, (lower right) The Savings and Consignments House

Source: personal collection of F.-C. Merciu

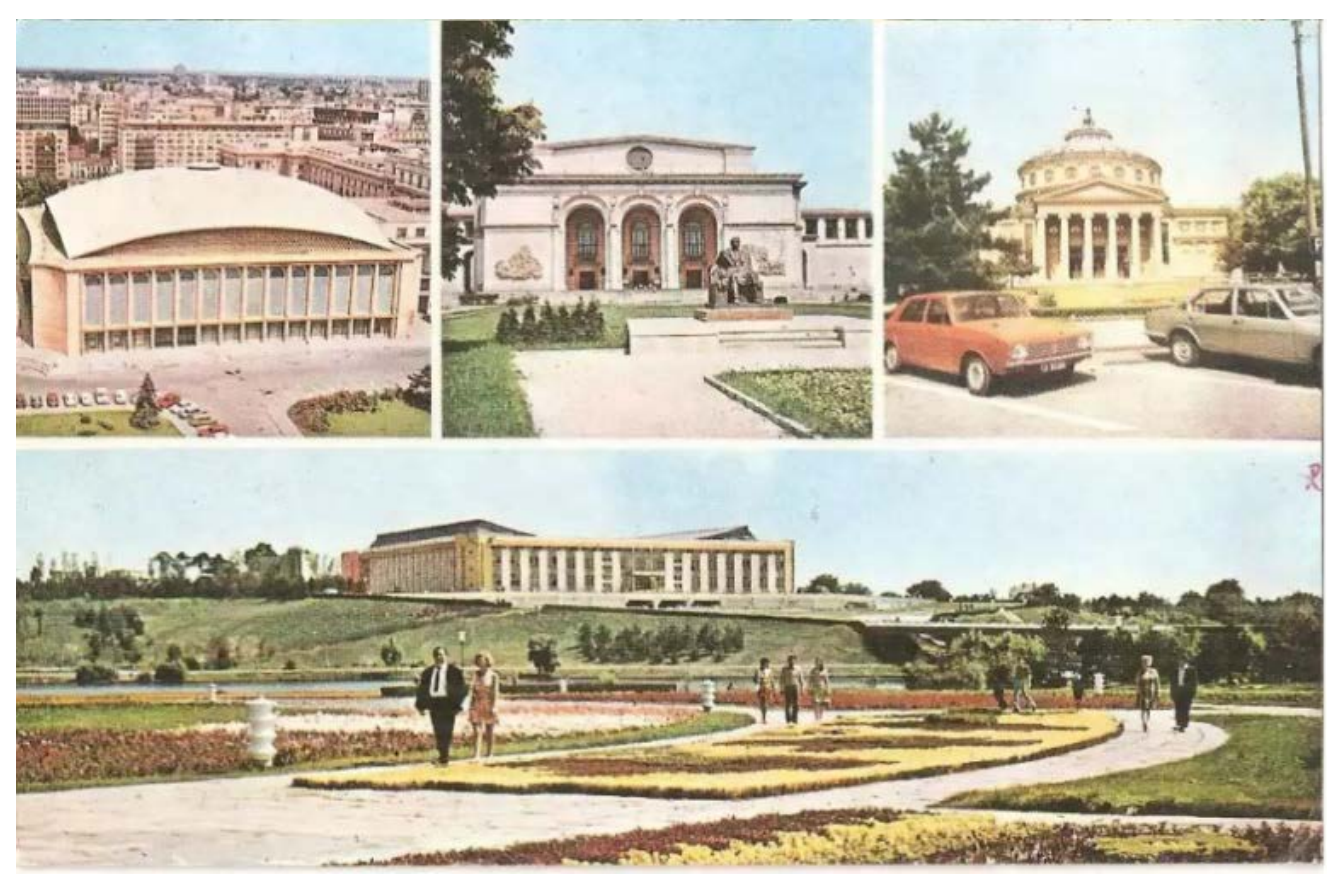

Figure 18: Collage postcard: (first line, from left to right) The Palace Hall, The Romanian Opera, The Athenaeum, (second line) overview of the Palace Hall 


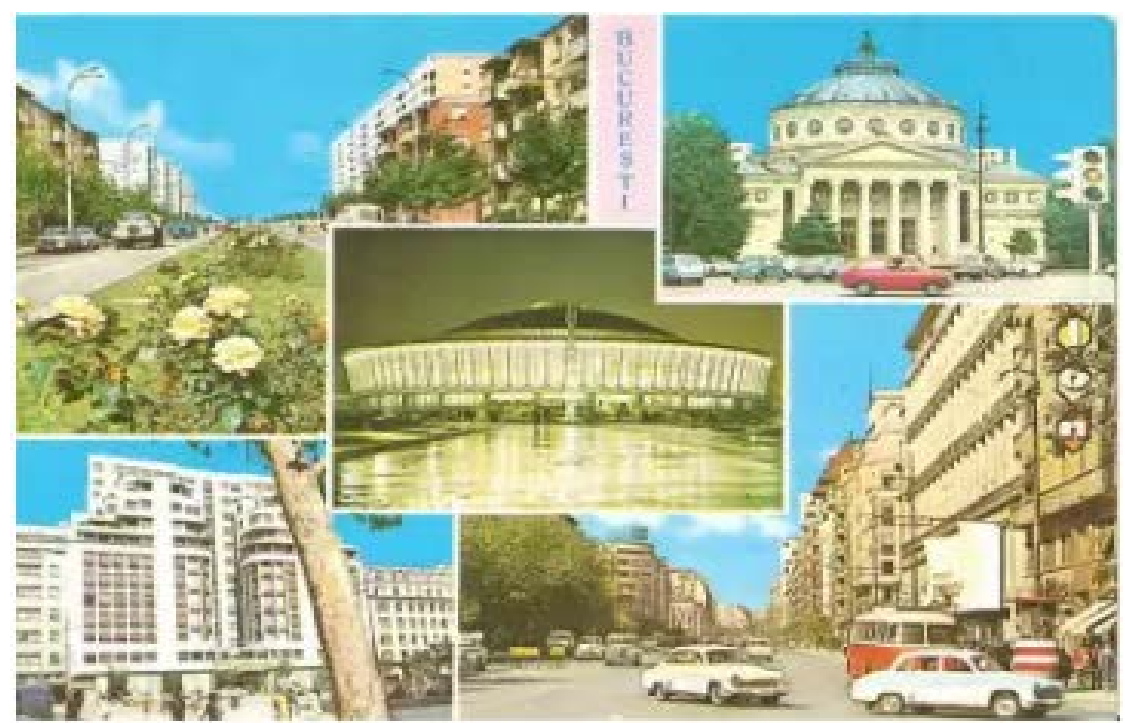

Figure 19: Collage postcard with (top left) Dimitrie Cantemir Boulevard, (top right) The Athenaeum, (centre) The State Circus, (bottom left) Ambassador Hotel, (top right) Dalles Hall

Source: personal collection of F.-C. Merciu

The tourist promotion through postcards is also reflected by the selection of some images inside the Athenaeum, being represented even the fresco (Figures 20, 21). For almost a decade, the fresco was hidden from the representatives of the communist regime by cove ring it with red velvet, due to fears that the communist leaders would intervene to change the images dedicated to the royal family. Until the construction of the Palace Hall, the Atheneum building was used for various activities of the members of the Romanian Communist Party (e.g. the congress for the creation of the Romanian Communist Party) (Zamfirescu et al., 1976).

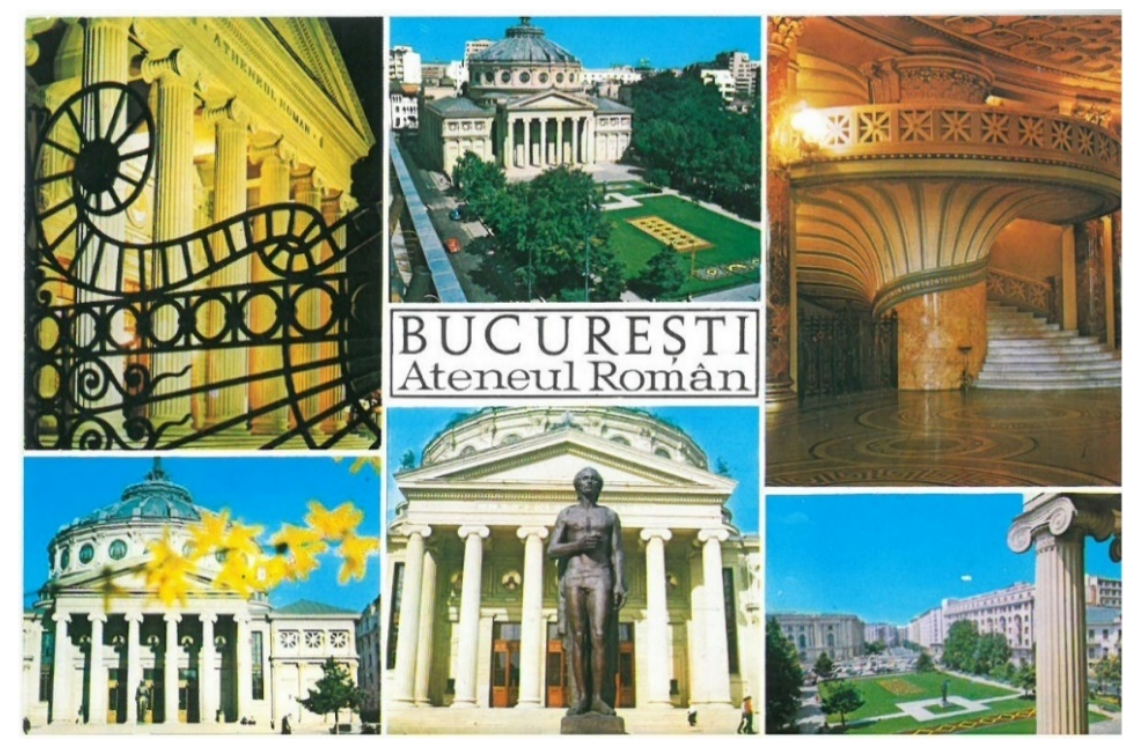

Figure 20: Circulated collage postcard consisting of images in which the Athenaeum is represented (dating: the year 1973 is indicated by the sender) 

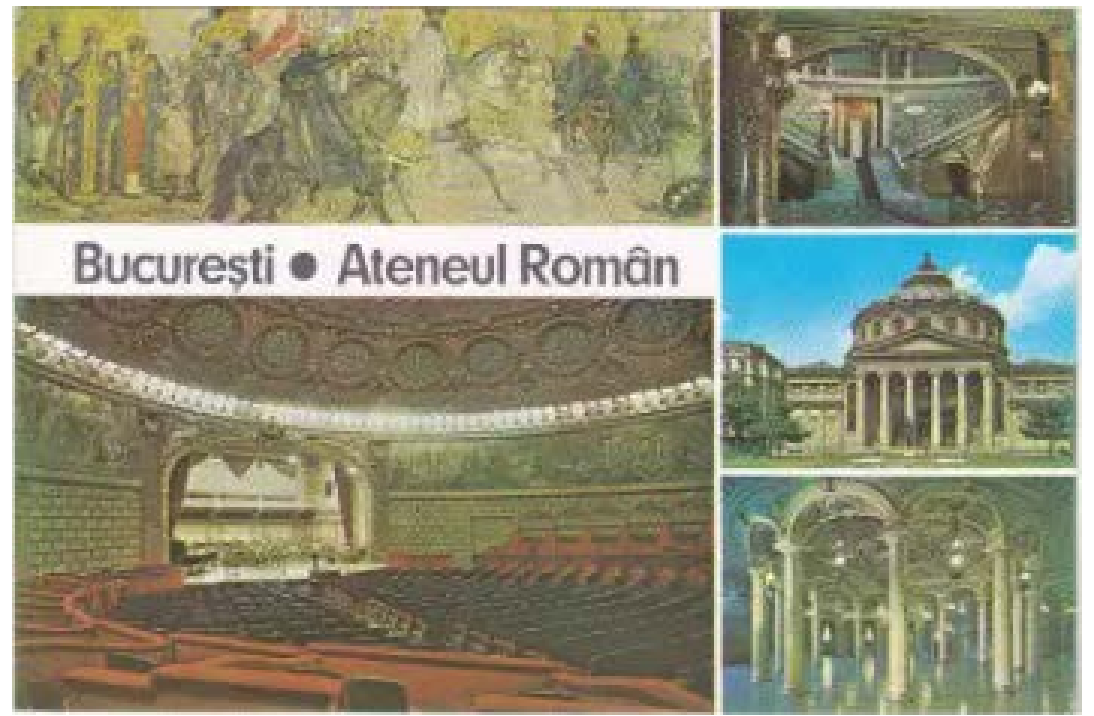

Figure 21: Collage picture postcard with images of the Romanian Athenaeum Source: personal collection of F.-C. Merciu

We also identified recent postcards depicting the Athenaeum in a collage of images along with other symbolic landmarks of Bucharest: the Museum of Art Collections, the National Art Museum, the Village Museum, the Parliament Palace and commemorative monuments (Arc de Triomphe) (Figure 22). Recent postcards have been purchased from bookstores in order to identify whether the Athenaeum is among the tourist attractions that are being promoted through postcards at present.
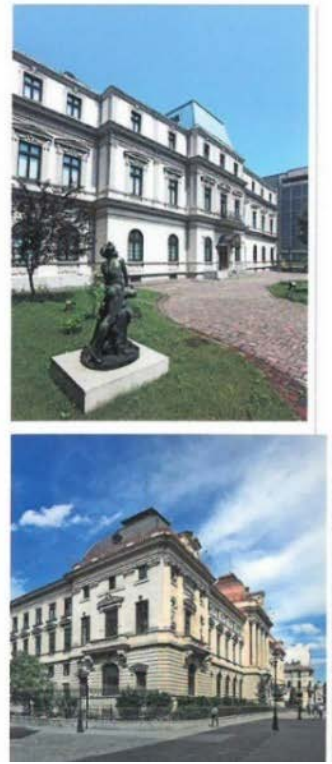

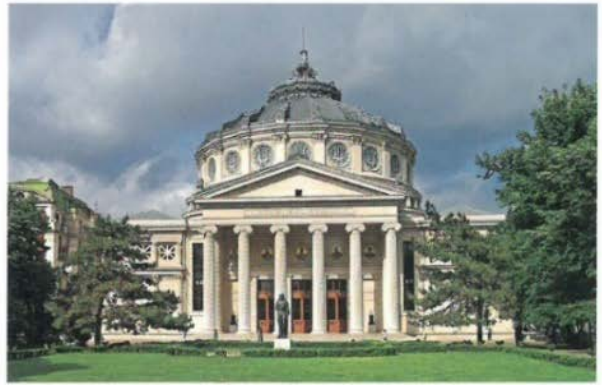

Bucureşti

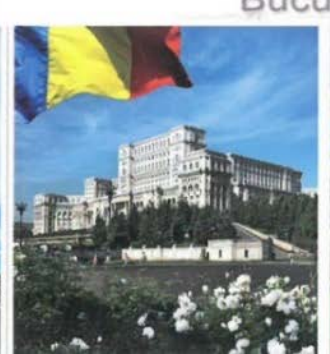

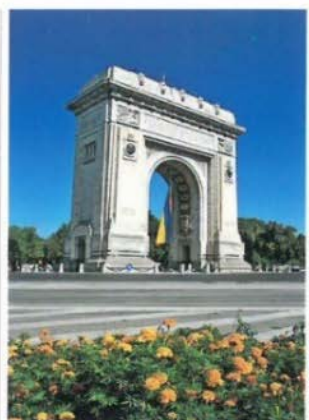

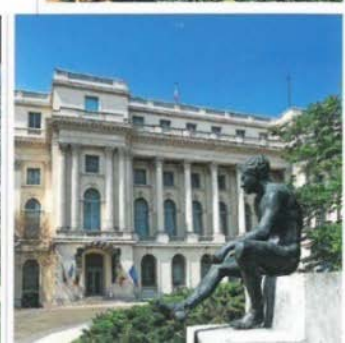

Figure 22: Postcard with buildings and symbol monuments of Bucharest: (first line, from left to right) The Museum of Art Collections, The Romanian Athenaeum, The Arc de Triomphe;

(second line, from left to right) The National Bank, The Parliament Palace, windmill from Tulcea County within the Village Museum, The National Art Museum of Romania/ Royal Palace

(published in 2016) 
Heritage buildings are given increased visibility and are intelligible through visual culture (Staiff, 2014, quoted by Edwards, 2019) due to historical, architectural, aesthetic values, thus representing the resonant iconic or representative edifices (Maroşi, 2017; Otahel' et al., 2018; Watson \&Waterton, 2010).

The Athenaeum building has been represented in postcards since one year after its inauguration and until now, for a period of 132 years, which draws attention to the fact that the purpose of its creation as a palace of arts open to the public was permanently fulfilled, this being a symbolic building both for the capital city and nationally. The picture postcards in which the Athenaeum is represented in the first years from its construction indicate the popularity of this cultural edifice among Bucharest society since the mid-nineteenth century, offering the public the opportunity to participate in various cultural activities: concerts, conferences, and art exhibitions.

Among the oldest postcards depicting the Athenaeum Palace are those made by foreign photographers (e.g. Franz Duschek settled in Romania). On some postcards, it is written the name of the Athenaeum and its function ("House of music" - "Musiquesaal") in languages of international circulation (French, German), which indicates the importance of the building as a symbol of the capital city, especially since it was built at a time when Bucharest was going through a stage of urban development marked by the construction of several buildings with architectural value, in neoclassical style of French influence. As a result, Bucharest was named the "Little Paris" due to the buildings with architectural value and the atmosphere generated by the intense urban socio-cultural life (Bogan et al., 2017).

Monuments are the basic resources of cultural tourism and often the image of cities is associated with representative monuments (Otahel' et al., 2018). Their location and the urban fabric, as the main precondition of visual perception (visibility conditions), influence the visibility of the monuments. For example, the physical appearance of the urban environment (readability), as the main object of visual perception, is assessed in urban planning by identifying the best places to view the selected monuments, the visible part (readable, impressive) and the visible size (surface) of the monument (Otahel'et al., 2018, p. 56).

One of the best places to visualize the Athenaeum is from Știrbei Vodă Street, oriented perpendicular to Calea Victoriei (Figure 23). The visibility of the palace, from this point, is also favoured by the slope of the land which registers a slight decrease from Calea Victoriei to Știrbei Vodă Street, the Athenaeum being located on a higher ground.
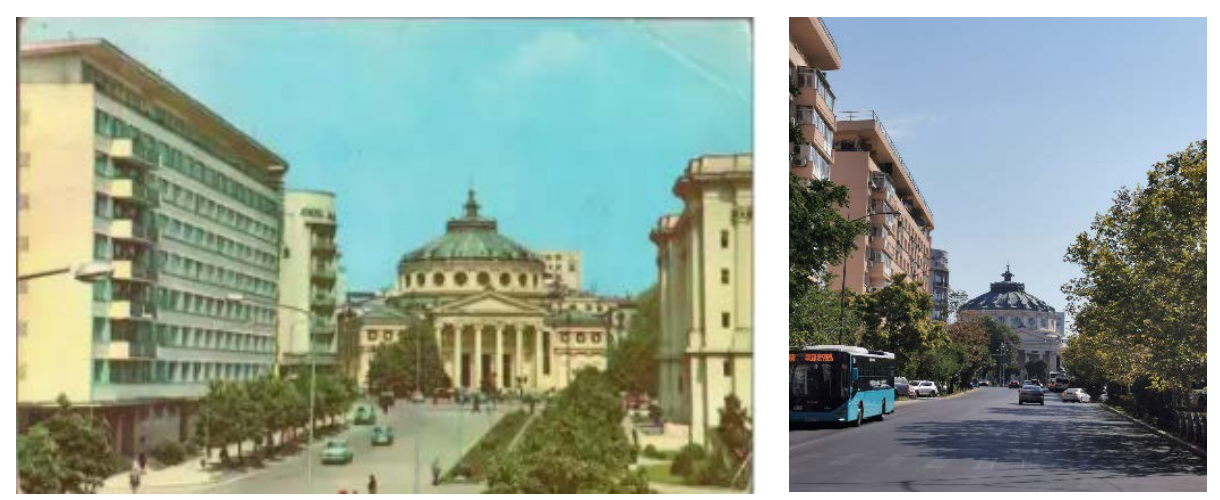

Figure 23: The Athenaeum viewed from Știrbei Vodă Street: (left) 1970s postcard, (right) July 2020 Source: postcard from the personal collection of F.-C. Merciu; photograph by F.-C. Merciu 
On Calea Victoriei, the Athenaeum can be seen from the Art Museum; coming from Victory Square, the visibility of the Athenaeum is reduced because of the Athénée Palace Hilton Hotel. Other better angles of visibility are obscured by taller buildings that were built later, such as the blocks of flats located on Nicolae Golescu Street (formerly Episcopiei Street), built in the interwar period behind the Athenaeum, or the blocks of flats on Magheru Blvd. (ONT Block, Lido Hotel).

The visual imagery interpretation of a monument must be made in its overall social, cultural, but also political context, in the sense that the relations within society, but also in politics, are identified through visual images (Marjanovic, 2004). At the same time, postcards represent an active form of writing history, a complex process of representing the urban past through the careful organization of images, allowing its interpretation (Marjanovic, 2004, p. 571).

The first relationship of the Athenaeum building with the political sphere was marked by a very important moment in the history of Romania, when, in the Great Hall, the ratification of the Union of Bessarabia, Bukovina and Transylvania with the Kingdom of Romania was voted on December 29, 1919 (Adamescu, 1953, p. 145). Currently, the most recent connection of the Athenaeum with the country's political activity is its hosting of the opening ceremony for the Romanian Presidency of the European Union Council, on January 10, 2019. During the ceremony, a concert was held by the European Union Orchestra (ensemble of musicians from the 28 member states) and the "George Enescu" Philharmonic Choir, under the coordination of Iosif Ion Prunner. Romania's presidency of the EU Council ended in June 2019 and was marked by the organization of an extraordinary concert held by the Romanian Youth Orchestra at the Romanian Athenaeum.

In time, representations of the Athenaeum were associated with symbols that were closely linked to its cultural value. The influence of the political factor in the transmission of message $s$ through visual imagery is also noticeable. In the old postcards (end of $19^{\text {th }}$ century and the first part of the $20^{\text {th }}$ century), visual imagery highlights the symbol status of the Athenaeum for the Romanian culture, as well as its quality of recreation space due to the presence of the garden. During the communist period, the Athenaeum is represented in numerous postcards, in which its status as a symbolic building of Bucharest is underlined, especially in the postcards in which it is the only element represented. The detailed analysis of these postcards allows us to observe the frequency of changing the floral ornaments within the green space in front of the Athenaeum. This fact indicates the concern for arranging the green space to highlight an important cultural institution. Especially since in the first years after the establishment of the Romanian Communist Party, the Athenaeum was used by communist leaders to carry out a series of activities.

At the same time, in some postcards in which the Athenaeum is the only represented element, a series of details are "sneaked in," which refer to the political-administrative organization of the country, some postcards being edited to mark the $20^{\text {th }}$ anniversary of the Socialist Republic. Also, there are identified elements that appear frequently, namely the car brand produced in our country during that period ("Dacia") or in other countries of the communist bloc ("Skoda," Czechoslovakia), indirectly highlighting the industrial production that represents the pillar to the development of the country.

There are also a series of postcards organized in the form of collages, in which there are represented, along with the Athenaeum, buildings erected during the communist period, usually monumental in terms of size, these occupying the central place in the postcard, and 
the Athenaeum is represented in a smaller medallion. Buildings such as Casa Scînteii, the Palace Hall or other buildings such as the State Circus were frequently represented in order to highlight the direction of the Communist Party to create the necessary socio-cultural infrastructure to modernize cities and to give the population the opportunity to participate in cultural activities. On the collage type postcards, in which there are represented symbolic buildings of the communist regime, the country's coat of arms is also present.

In visual culture, the role of the political factor is relevant because, in many countries, the production of postcards is managed by the state. Photographs, and especially postcards, have been used to reinforce the feeling of "publicity" (Edwards, 2019), being vital vehicles for advertising while mapping public space and aiming at the cognitive improvement of their audience (Latour, 2005; Warner, 2002, quoted by Edwards, 2019, p. 25).

It should be noted that many of the postcards in which the Athenaeum is represented also aim to promote the city of Bucharest from a tourist point of view, by referring to the most representative buildings, especially since some of them were published by the Official Tou rist Office (detail which is passed on the back). In a period when culture was censored, a previously created cultural institution is intensely promoted, both in the form of prints and by organizing the "George Enescu" Festival in 1958, even if its frequency has decreased since the 1980s (organized once every three years).

Iconic buildings have the potential to incorporate a special relationship with place and people (Elhagla, Nassar \& Ragheb, 2020). The construction of iconic buildings produces various impacts. From the building itself, the place where it is created, to how it influences the area in its vicinity and the community (e.g. improving the quality of life: recreational opportunities) (Elhagla, Nassar \& Ragheb, 2020). The social significance of a monument (considered not only as a building) (Kepczynska-Walczak \& Walczak, 2015, p. 2) results from the connection of personalities and historical events with that monument. The cultural and social importance of the Athenaeum is closely linked to the symphonic concerts of the Philharmonic Society, be ing the place where well-known artists debuted: George Enescu, Dinu Lipatti, Cella Delavrancea, Ion Voicu, George Georgescu, Dimitrie Diniciu, and Ionel Perlea. Since 1958, the Athenaeum has hosted "George Enescu" International Music Festival, initiated in memory of the great Romanian composer and violinist. Every year, the festival is attended by orchestras (Vienna Philharmonic, Stockholm Philharmonic, London, Royal Amsterdam Orchestra, etc.) and prestigious musicians, this cultural event competing with festivals organized in other European cities (Salzburg, Lucerne) (Figure 24).

The epidemic caused by the SARS-COV 2 virus directly affected the cultural life of the capital city by closing all cultural institutions (theatres, museums, The Athenaeum - "George Ene scu" Philharmonic). However, feeling the need to revitalize the cultural life of Bucharest, the representatives of the Athenaeum's management organized between July 15 and August 27, 2020, the International Festival "Magic Summer 2020" (ninth edition), in the courtyard of the Athenaeum, under the title "Beethoven's Year in Bucharest" (Figure 25). The open-air organization of the international music festival was the only viable solution in the respective context. It was a success. Every Wednesday and Thursday evening during the festival, music could be heard from the Philharmonic Garden. The number of seats in front of the Athenaeum was limited to respect social distance.

The Athenaeum constantly represents a source of inspiration for Romanian artists, the building being rendered in numerous paintings made in oil or watercolour. In addition, due to the fact that the Athenaeum is located in an area that preserves the atmosphere of the $19^{\text {th }}$ century, it 
was selected for its historical setting for film productions (most recently for the films "The Asset," January 2020, "A Christmas Prince: The Royal Baby," 2019, a scene from the HBO series "Killing Eve," filmed in the lobby of the Athenaeum which, in the movie, was called the "Radozhny" cafe in Moscow, to which are added some scenes filmed on N. Golescu Street, behind the Athenaeum which, in the movie, are specified as located in Paris.

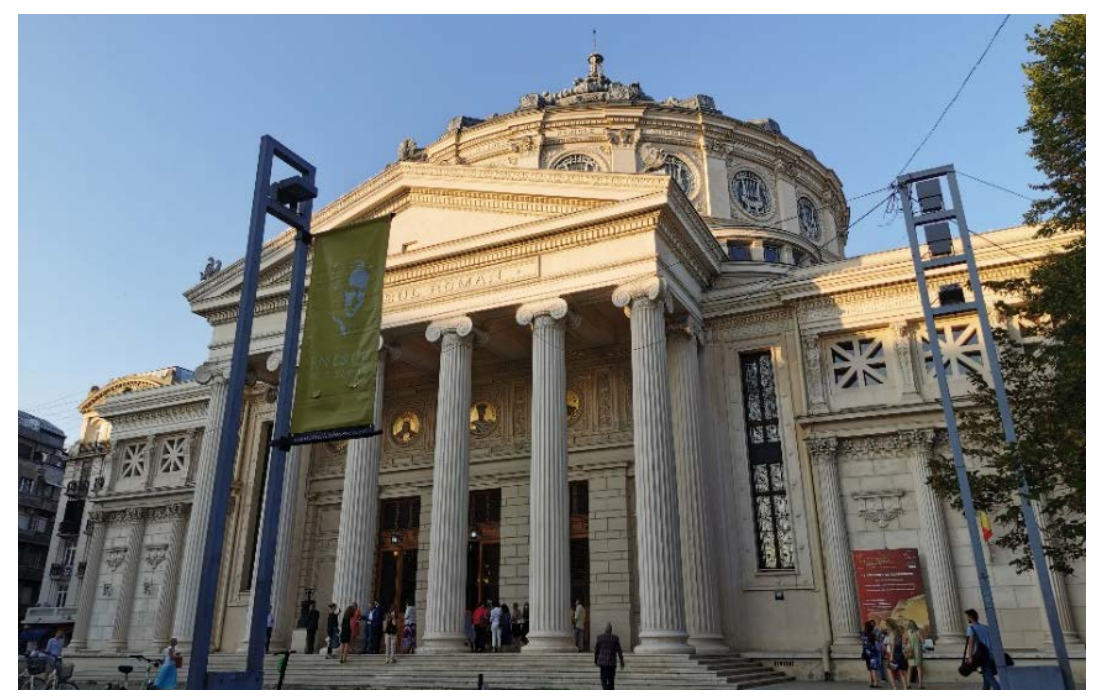

Figure 24: The Athenaeum in celebration - "George Enescu” Festival (September 2019)

Source: photograph by F.-C. Merciu

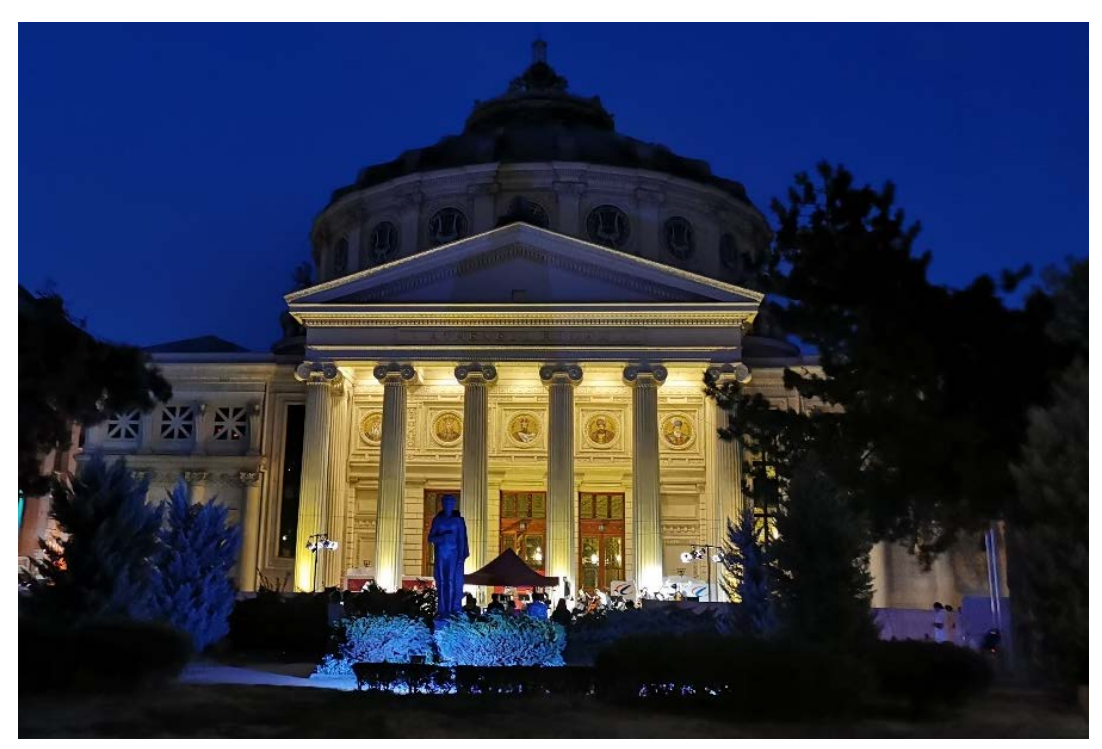

Figure 25: Outdoor concert at the "Magic Summer" Festival (August 2020)

Source: photograph by F.-C. Merciu

The Athenaeum, through its associated values (oldness, architecture, aesthetics), stands out among the most visited cultural objectives of Bucharest. In recent years, the Athenaeum has been included in a tourist circuit created at the initiative of associations of young enthusiasts, who organize free tours for foreign tourists every afternoon (Figure 26a, b). 

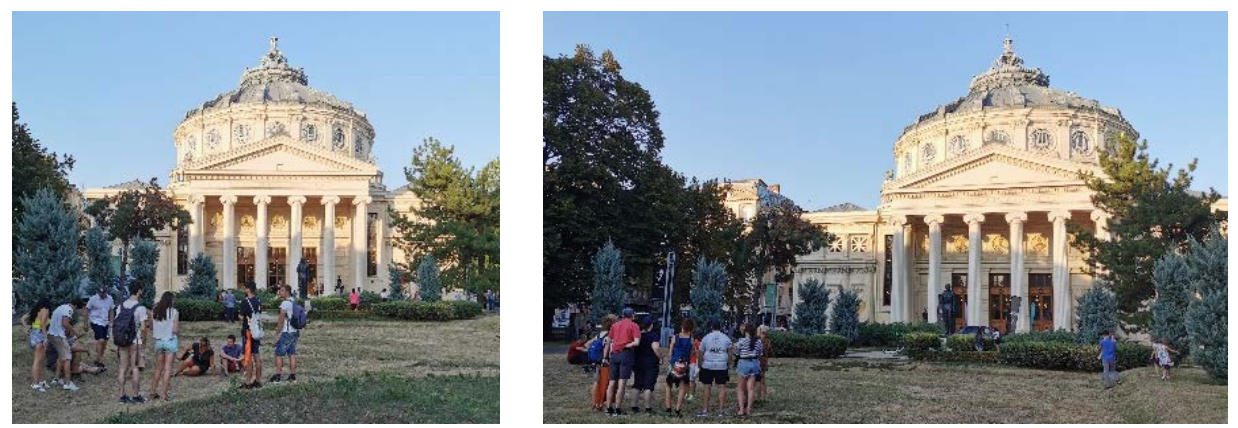

Figure 26: Guided tourist groups visiting the Athenaeum in June (left) and July 2019 (right) Source: photographs by F.-C. Merciu

The connection of the Athenaeum with its public is realized beyond music, as the building itself is an attraction for Romanian tourists. Moreover, the historic buildings on Calea Victoriei, including the Athenaeum, were highlighted during the International Festival of Lights "Spotlight," through interactive installations and light shows. "Spotlight" is one of the most popular open-air festivals in Bucharest, where spectators can explore fascinating digital worlds, alternative landscapes, sensory or audio-visual experiences enabled by light-based artistic installations.

\section{CONCLUSIONS}

The built heritage elements have characteristics such as uniqueness and irreversibility due to the multiple meanings they incorporate (oldness, architectural value, aesthetics, symbolism). Architectural monuments provide a distinct urban territorial identity, being frequently associated with the tourist image of cities. Visual imagery is an argument, influenced by sociocultural and political factors, in the selection from the mass of architectural monuments of significant buildings for local and / or national culture to be promoted among the public. These monuments generate a strong image among both visitors and the local population.

The cultural heritage of a city ensures, through its antiquity and the meanings it encompasses, the creation of a codified framework. Through the various forms of representation, the symbols associated with iconic buildings are also transmitted. In this coded framework, there are a series of symbols through the decryption of which the cultural identity of urban centres can be discovered. Thus, the elements of visual imagery are useful not only for advertising, but they are also a means of understanding historical monuments.

The present study focuses on the interpretation of the symbols associated with the building of the Romanian Athenaeum, based on the analysis of visual imagery elements (postcards and photographs), over a period of 132 years, from its inauguration to the present. Conceived by the founding members as a cultural institution of reference at national level, the Romanian Athenaeum has represented, since the beginning of its construction, a dynamic, vibrant space from a cultural, artistic and political point of view, hosting important events, thus being permanently in relation to the public. From a cultural and artistic point of view, the Romanian Athenaeum hosted events with great impact on the public, going beyond Romania's borders, attracting well-known artists, but also beginners, from various countries. Thus, the Romanian 
Athenaeum acquired the status of a symbolic building of national culture, which also contributed to its constant representation in the public space through visual imagery. Most of the time, the influence of the political factor stimulated its publicity.

Its multiple meanings and constant representation, regardless of the historical stage, have determined that it is one of the most visited tourist objectives of Bucharest. From our perspective, it was possible, through a detailed interpretation, to underline the role played by the Romanian Athenaeum as a "palace of sciences and arts," through historical illustrations, also pointing out the relationships established with various categories of public, contributing to the construction of territorial identity.

\section{Acknowledgements}

This article was supported by a grant of the Romanian Ministry of Research and Innovation CCCDI - UEFISCDI, project number 52PCCDI/2018 (PATCULT\#RO) PN-III-P1-1.2-PCCDI-20170686: "Complex multidisciplinary platform for integrative and systematic research of identities and tangible and non-tangible cultural heritage in Romania."

\section{REFERENCES}

ADAMESCU, Gh. (1931). Ateneul Român [The Romanian Athenaeum]. Boabe de grâu [Wheat Grains], 2(3), 138-150.

BALACl, A. (coord.) (2007). Dizionario Italiano-Romeno [Italian Romanian Dictionary]. Oradea: Gramar.

BEDATE, A., HERRERO, L.C., \& SANZ, J.A. (2004). Economic Evaluation of the Cultural Heritage: Application to Four Case Studies in Spain. Journal of Cultural Heritage, 5, 101-111.

BOGAN, E. CERCLEUX, A.L., CONSTANTIN, D.O., MERCIU, F.C., \& TUFEANU, R. (2017). L'mportance des festivals pour le tourisme de Bucarest. Annals of University of Bucharest, Geography Series, 22, 97-106.

CALOIANU, Ș. \& FIUP, P. (2009). Monumente Bucureștene [Monuments of Bucharest]. București: Editura Monitorul Oficial.

CERCEL, E. (2012). Marea frescă de la Ateneul Român - creația pictorului Costin Petrescu [The Grand Fresco from the Romanian Atheneum - Creation of Painter Costin Petrescu]. NOEMA, 11, 483-494.

CHYLIŃSKA, D. (2019). The Role of the Picturesque in Geoturism and Iconic Geoturist Landscapes. Geoheritage, 11, 531-543.

CONSTANTINESCU, D.-T. (1989). Construcții monumentale [Monumental Constructions]. București: Editura Ştiinţifică şi Enciclopedică.

CORA, D. (2014). Propaganda politică pentru și în timpul naționalizării comuniste [Political Propaganda for and during Communist Nationalisation]. Analele Banatului. S.N., Arheologie - Istorie [The Journal of Banat, Archeology - History], 22, 475-485.

COSKUN, H. (2018). The Historical Symbolizing of Istanbul City through Its Iconic Buildings. In Catalani, A., Nour, Z., Versaci, A., Hawkes, D., Sotoca, A., Ghoneem, M., \& Trapani F. (eds.), Cities' Identity through Architecture and Arts (pp. 147-152). London: Taylor and Francis Group.

DOĞAN, E. (2019). The Absent Presence of Abandoned Industrial Spaces in Belgrade: A Semiotic Study through Photographic Imagery. In Doğan, E. (ed.), Reinventing Eastern Europe: Imaginaries, Identities and Transformations (pp. 55-76). London: Transnational Press London.

DUȚU, A. (2001). Casa Cesianu din Strada Clemenței [Cesianu House in Clemenței Street]. București. Materiale de Istorie și Muzeografie [Bucharest. History and Museography Materials], 25, 238-244.

EDWARDS, E. (2019). Our Ancient Monuments: Visualizing Documents in Stone. Visual Anthropology Review, 35(1), 23-36. 
ELHAGLA, K., NASSAR, D.M., \& RAGHEB, M.A. (2020). Iconic Buildings' Contribution towards Urbanism. Alexandria Engineering Journal, 59, 803-813.

FILARMONICA „GEORGE ENESCU” (2020). Ateneul Român. „Inima culturii românești” [The Romanian Athenaeum. “Heart of the Romanian Culture"]. Retrieved May 12 2020, from https://www.fge.org.ro/filarmonica/istoric-ateneu/

FILITTI, G. (2016). Ateneul Român. O clădire emblematică a orașului [The Romanian Athenaeum. An Emblematic Building of the City]. Ziarul Metropolis. Cotidian Cultural. Retrieved May 12 2020, from https://www.ziarulmetropolis.ro/ateneul-roman-o-cladire-emblematica-a-orasului/

GRIṬCO, A. (2007). Cartea poștală cu suport publicitar din patrimoniul Muzeului Național de Istorie a Moldovei (sf. sec. XIX - prima jumătate a sec. XX) [The Postcard as Advertising Support from the National Museum for the History of Moldova (End of the $19^{\text {th }}$ Century - the First Half of the $20^{\text {th }}$ Century]. Tyragetia, 11(2), 337-344.

HODOȘ, N. \& SADI IONESCU, Al. (1913). Publicațiunile Periodice Românești (ziare, gazete, reviste) descriere bibliografică, tom 1, catalog alfabetic 1820-1906, Academia Română [Romanian Periodicals (Newspapers, Gazettes, Magazines), Bibliographical Description, Tome 1, Alphabetical Catalogue, The Romanian Academy]. București: Librăriile Socec \& Comp. și C. Sfetea.

ILOVAN, O.-R. \& MAROȘI, Z. (2018). Markers of Visual Identity: Industrial Sites and Landscapes in Picture Postcards during the Socialist Period of Romania. Acta Technica Napocensis: Civil Engineering \& Architecture, 61(3), 132-151.

ILOVAN, O.-R. (2019). Visual Imagery and Propaganda during Communist Romania (1948-1989): Picture Postcards as a Tool. Connections. A Journal for Historians and Area Specialists, www.connections.clioonline.net/article/id/artikel-4767

ILOVAN, O.-R., URSU, C.-D., \& DULAMĂ, M.E. (2019). Visual Imagery and Learning about Cultural Landscapes during Geography University Studies. Romanian Review of Geographical Education, 8(1), 64-96.

IORGULESCU, F., ALEXANDRU, F., CREȚAN, G.C., KAGITCI, M., \& IACOB, M. (2011). Consideration Regarding the Valuation and Valorization of Cultural Heritage. Theoretical and Applied Economics, 18(12), 15-32.

IPATE, M. (2006). Palatul Dinicu Golescu între anii 1812-1866 [Dinicu Golescu Palace between 1821 and 1866]. București. Materiale de Istorie și Muzeografie [Bucharest. History and Museography Materials], 20, 29-44.

JAWORSKI, A. (2010). Linguistic Landscapes on Postcards: Tourist Mediation and Sociolinguistic Communities of Contact. Sociolinguistic Studies, 4(3), 569-594.

JONES-TRAVERS, J. (2018). Placemaking through Postcards of Port Arthur. Historic Environment, 30(1), 64-79.

KAYMAZ, I. (2013). Urban Landscapes and Identity. In Ozyavuz, M. (ed.), Advances in Landscape Architecture (pp. 739-760). Rijeka: InTech.

KEPCZYNSKA-WALCZAK, A. \& WALCZAK, B.M. (2015). Built Heritage Perception through Representation of Its Atmosphere. Ambiances, 1, 1-15.

KHARITONOV, A., SMIRNOVA, O., \& VILENSKII, M. (2019). Principals of Green Architecture for the Historical Part of Saint-Petersburg. Urbanism Architecture Constructions, 10(2), 103-112.

LEARY, W.H. (1985). Archival Appraisal of Photographs: A RAMP Study with Guidelines. General Information Programme and UNISIST: United Nations Educational, Scientific and Cultural Organization. Retrieved September 26 2020, from: https://unesdoc.unesco.org/ark:/48223/pf0000063749

MAHGOUB, Y. (2007). Architecture and the Expression of Cultural Identity in Kuwait. The Journal of Architecture, $12(2), 165-182$.

MARECI-SABOL, H. \& PURICI, Ș. (2020). Reading the Image: Modernization and Identity as Reflected in Postcards from Bukovina at the Turn of the 20th Century. Transylvanian Review, 29(1), 92-102.

MĂRGĂRIT, S. (2019). Salutări din Bucureșci. Voiaj în Belle Époche [Greetings from Bucharest. Voyage in Belle Époche]. Bucharest: Monitorul Oficial R.A. Publishing House.

MARJANOVIC, I. (2004). Postcards and the Making of Architectural History: The Cases of Alvin Boyarsky and Rem Koolhaas. 92 ${ }^{\text {nd }}$ ACSA Annual Meeting, Miami, March 18-21, 2004, 571-577.

MAROȘI, Z. (2017). Representation of Local Identity through Landmarks: The Rehabilitation of Rupea Fortress, Romania. Territorial Identity and Development, 2(1), 31-46. 
MÂRZA, R. (2018). Frânturi din istoria Clujului în Belle Époque prin cărți poștale [Pieces from the History of Cluj in Belle Époque through Postcards]. In Lupescu Makó, M. (coord.), Costea, I., Ghitta, O., Sipos, G., \& RüszFogarasi, E. (eds.). Cluj - Kolozsvár - Klausenburg 700. Várostörténeti Tanulmányok. Studii de Istorie Urbană [Studies of Urban History] (pp. 259-269). Kolozsvár: Erdélyi Müzeum - Egysület.

MASON, R. (2002). Assessing Values in Conservation Planning: Methodological Issues and Choices. In de la Torre, M. (ed.), Assessing the Values of Cultural Heritage Report (pp. 5-30). Los Angeles: The Getty Conservation Institute. $\quad$ Retrieved January $12 \quad 2020, \quad$ from https://www.getty.edu/conservation/publications_resources/pdf_publications/pdf/assessing.pdf.

MATEČIĆ, I. (2016). Specific Characteristics of the Tangible Cultural Heritage Valuation Process in Tourism. Acta Turistica, 28(1), 73-100.

MELLINGER, W.M. (1994). Towards a Critical Analysis of Tourism Representations. Annals of Tourism Research, 21(4), 756-779.

MERCIU, C., IANOȘ I., MERCIU, G.-L., ROY, J., \& POMEROY, G. (2018). Mapping Accessibility for Earthquake Response in the Historic Urban Centre of Bucharest. Nat. Hazards Earth Syst. Sciences, 18, 2011-2026.

MERCIU, F.C., CERCLEUX, A.L., \& MERCIU, G.L. (2020). Identification and Interpretation of the Territorial Identity Elements of a Small Industrial Town Using Postcards. Case Study: Anina, Romania. In Banini, T. \& Ilovan, O.R. (eds.), Representing Place and Territorial Identities in Europe: Discourses, Images, and Practices, under review and provisionally accepted by Springer.

MERCIU, F.C., IANOȘ, I., CERCLEUX, A.L., \& MERCIU, G.L. (2020). Evaluation of the Economic Values of Urban Heritage in the Central Area of Ploieşti Municipality. Proceedings of $21^{\text {st }}$ Edition of International Conference Knowledge-Based Organization 2020, Sibiu, Romania, Nicolae Balcescu Land Forces Academy Sibiu, 11-12 June 2020, 26(2), 58-62.

MILMAN, A. (2012). Postcards as Representation of a Destination Image: The Case of Berlin. Journal of Vacation Marketing, 18(2), 157-170.

MOHAMMAD, A.S. El-D., EL-EASHY, A.M., \& ALAZAB, M.T. (2014). The Urban Role of Iconic Buildings in Intermediate Cities: Mansoura City as a Case Study. Mansoura Engineering Journal, 39(4), 11-28.

MUNASINGHE, H. (2000). Heritage Protection and Cultural Identity. Nordisk Arkitenkturfoskning, 3, 75-81.

NAVRUD, S. (2005). Valuing Cultural Heritage - Lessons Learned. Structural Studies. Repairs and Mantenance of Heritage Architecture, 9, 95-100.

ONCIUL, D. (1906). Alegerea regelui Carol I al României: conferință ținută pe 9 aprilie 1906 la Ateneul Român [The Election of Charles I of Romania: The Conference Held on the $9^{\text {th }}$ of April 1906 at the Romanian Athenaeum]. București: Editura Socec.

OŤAHEL', J., IA, V., HLAVATÁ, Z., \& PAZÚR, R. (2018). Visibility and Perception Analysis of City Monuments: The Case of Bratislava City Centre (Slovakia). Moravian Geographical Reports, 26(1), 55-68.

PAPPASOGLU, D. (1891). Istoria fondărei orașului București capitala Regatului Român de la anul 1330 până la 1850 [The Creation History of Bucharest, the Capital City of the Romanian Kingdom, from 1330 to 1850]. București: Tipografia Universul.

PIPINIS, J. (2014). A Toolbox for Iconic Architecture. Proceedings of $5^{\text {th }}$ International Conference on Competitions 2014, Delf (pp. 433-456). Retrieved September 14 2020, from: https://repository.tudelft.nl/islandora/object/uuid\%3A6b4c6089-06b6-4128-b4b0-4d0cce5498c9

SÂRBU, C. (coord.) (2010). Marea refacere a Ateneului Român. 1903-2003 [The Great Restoration of the Romanian Athenaeum. 1903-2003]. Caietele Filarmonicii "George Enescu" [Notebooks of "George Enescu" Philharmonic]. București: Editura Anima.

SAWYER, C.F. \& BUTLER, D.R. (2006). The Use of Historical Picture Postcards as Photographic Sources for Examining Environmental Change: Promises and Problems. Geocarto International, 21(3), 73-80.

SILVIU (2012). Ateneul Român 1957 [The Romanian Athenaeum 1957]. I Think Therefore I Blog. Retrieved May 12 2020, from https://dunedenisip.wordpress.com/2012/05/08/ateneul-roman-1957/ 
THROSBY, D. (2002). Cultural Capital and Sustainable Concepts in the Economics of Cultural Heritage. In Torre, M. (ed.), Assessing the Values of Cultural Heritage Research Report (pp. 101-117). Los Angeles: The Getty Conservation Institute. Retrieved January 12 2020, from https://www.getty.edu/conservation/publications_resources/pdf_publications/pdf/assessing.pdf.

TUlBURE, I. (2013). From Casa Scânteii to Casa Poporului and Back. Architecture as Icon of a Totalitarian Regime. Studies in History \& Theory of Architecture, 1, 79-89.

TURIST ÎN BUCUREȘTI [Tourist in Bucharest] (2013). Informații despre istoria Bucureștiului, poze vechi, trasee pietonale [Information about the History of Bucharest, Old Photographs, Pedestrian Routes]. Retrieved May 12 2020, from https://turistinbucurestiro.blogspot.com/2013/06/ateneul-roman.html?m=1

ULUĞ, E. (2020). An Investigation into the Connotations of Iconic Buildings by Using a Semiotic Model of Architecture. Social Semiotics. Retrieved September 26 2020, from: https://www.tandfonline.com/doi/full/10.1080/10350330.2020.1756590

UNITED NATIONS DEPARTMENT OF ECONOMIC AND SOCIAL AFFAIRS (UNDESA) (2012). Shanghai Manual: A Guide for Sustainable Urban Development in the 21st Century. Retrieved February 6 2020, from https://sustainabledevelopment.un.org/content/documents/shanghaimanual.pdf

VUKONIĆ, B. (2018). Similarities and Differences of Historical Cities as Tourism Destinations. Acta Turistica, 30, $\mathrm{SI}$, 83-94.

WATSON, S. \& WATERTON, E. (2010). Reading the Visual: Representation and Narrative in the Construction of Heritage. Material Culture Review, 71, 84-97.

YALÇINKAYA, Ș. (2020). Iconic Buildings in Urban Sustainability. Journal of Science and Technology A-Applied Sciences and Engineering, 21(2), 282-293.

YOUSSEF, M.M. (2018). Design Ideology through Architectural Identity: A Hybrid Dynamic Potential. In Catalani, A., Nour, Z., Versaci, A., Hawkes, D., Sotoca, A., Ghoneem, M., \& Trapani, F. (eds.), Cities' Identity through Architecture and Arts (pp. 183-190). London: Taylor and Francis Group.

YUNG, E.H.K., YU, P.L.H., \& CHAN, E.H.W. (2013). Economic Valuation of Historic Properties: Review and Recent Developments. Property Management, 31(4), 335-358.

ZAMANI, L. (2015). Fotografii și fotografiile de odinioară [Old Times Photographers and Photographs]. București. Materiale de Istorie și Muzeografie [Bucharest. History and Museography Materials], 29, 112-120.

ZAMFIRESCU, I., CÂNDEA, V., \& MOGA, V. (1976). Ateneul Român. Monografie [The Romanian Athenaeum. Monography]. București: Editura Ştiinţifică şi Enciclopedică. 